\title{
Learning risk management of geohazards in practice with free and open-source web-GIS based platform: RISKGIS
}

\author{
Zar Chi Aye ${ }^{1,2}$, Roya Olyazadeh ${ }^{1,2}$, Marc-Henri Derron ${ }^{1,2}$, Michel Jaboyedoff ${ }^{1,2}$, Johann Lüthi ${ }^{2}$ \\ ${ }^{1}$ Institute of Earth Sciences, University of Lausanne, Lausanne, Switzerland \\ $5 \quad{ }^{2}$ Faculty of Geosciences and Environment, University of Lausanne, Lausanne, Switzerland
}

Correspondence to: Zar Chi Aye (zarchi.aye@unil.ch)

\begin{abstract}
How do environmental risk systems function?" is the main underlying question to be answered by students learning environmental risk. Under the framework of the Innovative Teaching project, an open-source, interactive and collaborative web-GIS application (RISKGIS) is developed for students in learning and understanding of environmental risk

10 systems with a focus on geohazards and risk. The aim is for students to better understand and become familiarized with approaches used by experts as well as for teachers to better evaluate and monitor student learning, through a practical application with real case studies and hand-on exercises. To identify the possibility and applicability of the developed learning platform, a series of practical exercises is carried out with undergraduate and postgraduate students during the spring and autumn semesters of the environmental risk, and advanced risk and vulnerability courses of the University of

15 Lausanne. A total of three exercises are conducted starting from the rapid risk calculation (individual) exercise to more complex risk management (individual and group) exercise with different case studies and functionalities of the learning platform. Depending on the exercises, students are asked to answer the test quiz, feedback questionnaires and group reports (if requested) through the Moodle platform to evaluate the performance of the students, exercises and the RISKGIS platform. Average feedback results from three different exercises revealed that students found the exercises useful and interesting,

20 while a user satisfaction score of 7/10 and a system usability scale (SUS) of 64/100 is achieved, showing that several aspects of the RISKGIS learning platform could be further improved with suggestions and feedback of the students.
\end{abstract}

\section{Introduction}

As natural hazards are location dependent, risk management activities can benefit from geographical representations. Geospatial technologies such as Remote Sensing (RS) and Geographic Information Systems (GIS) are increasingly utilized 25 as useful decision support tools in natural hazards and risk management (Coppock, 1995; Thomas and Kemec, 2007; Manfré et al., 2012; van Westen, 2013). The rapidly growing technology such as GIS plays an important role in understanding and managing natural hazards, referenced to a geographical location (Carrarra and Fausto, 1995; Peggion et al., 2008). For example, in the process of risk assessment, GIS can be used to calculate potential damages in affected areas caused by a hazard event, helping risk managers and decision makers to take appropriate preventive measures. With regards to teaching 
Nat. Hazards Earth Syst. Sci. Discuss., doi:10.5194/nhess-2017-85, 2017

Manuscript under review for journal Nat. Hazards Earth Syst. Sci.

Discussion started: 1 March 2017

(c) Author(s) 2017. CC-BY 3.0 License.

and learning within natural hazards, environment and risk, GIS applications have been widely used as a supporting platform for effectively achieving goals of the science education such as utilization of the power of technology, development of data analysis and (spatial) thinking skills (Barstow, 1994; Gutierrez et al., 2002; Bodzin and Anastasio, 2006; Mitchell et al., 2008). Over the years, GIS technology benefited from the evolution of web, and with the advancement of technologies, it has

5 become possible not only to visualize and disseminate spatial data and information over the web but also to analyse, model and process interactively (Dragićević, 2004). Subsequently, Spatial Data Infrastructure (SDI), web-GIS and geo-visualisation tools have been applied in numerous works of the natural hazards community (Sugumaran et al., 2000; Mansourian et al., 2006; Müller et al., 2006; Sutanta et al., 2009; Aye et al., 2016a).

10 Particularly in teaching and learning, web-GIS platforms have become increasingly applied in instructional settings to overcome barriers such as cost, accessibility to hardware and software, and lack of technical support (Audet and Paris, 1997; Carver et al., 2004; Bodzin and Anastasio, 2006). These platforms can be easily accessible from web browsers without needing to use limited resources of the Lab and purchase GIS software. Moreover, the progress in web-GIS helped advancing collaborative and participative approaches in risk management (Dragićević and Balram, 2004). This in turn

15 facilitated the centralised sharing and analysis of data and information, especially in performing collaborative group exercises with students under the integrated risk management framework. Due to these several advantages, web-GIS platforms designed for different purposes in teaching and learning have been applied for subjects related to climate change, natural hazards and environmental risk management (Tobita et al., 2008; Frigerio and van Westen, 2010; Joost et al., 2012; Pechanec and Vávra, 2013; Careaga, 2014). Learning risk management through interactive web-GIS tools can be regarded as

20 a technology-supported, active learning activity (Aye et al., 2016c; Kos, 2009). Bonwell and Eison (1991, p. 2) defined "active learning" as an activity in which students are involved "in doing things and thinking about the things they are doing". This activity is meaningful and important, which contributes to the understanding of concepts to be learned (Wiggins and McTighe, 1998). Besides, the application of open-source technology combined with e-learning tool such as Moodle (Modular Object-Oriented Dynamic Learning Environment) could bring innovative pedagogical advantages and values to

25 conventional curricula and classroom practice, such as interactive and active learning, collaborative interaction between students, accessibility to a wide range of online resources from discussion forums to teaching materials, assessment and feedback (Brandl, 2005). These kinds of interactive learning platforms and activities could help increasing the motivation and interest of students in their studies.

30 Even though some teaching projects using web-GIS exist (Painho et al., 2001; Bodzin and Anastasio, 2006; Wang et al., 2016), they are almost exclusively used for the visualization and dissemination of spatial data with little capacity for edition and simulation of data. In particular for the estimation and management of natural hazards, risk analysis tools are generally intended for experts, rarely in the form of web-GIS, and inadequate for teaching (OFEV, 2016; RoadRisk, 2017; ZHA, 2017). Developing such a platform from scratch would be a considerable work, and therefore, taking the advantage of open- 
Nat. Hazards Earth Syst. Sci. Discuss., doi:10.5194/nhess-2017-85, 2017

Manuscript under review for journal Nat. Hazards Earth Syst. Sci.

Discussion started: 1 March 2017

(c) Author(s) 2017. CC-BY 3.0 License.
Natural Hazards

and Earth System

Sciences

Discussions

(c) (i)

source and previous related works done by authors (Aye et al., 2016a; Aye et al., 2016b; Olyazadeh et al., 2016), a platform named "RISKGIS" is developed for teaching under the framework of the Innovative Teaching project (FIP) of the University of Lausanne. RISKGIS is an open-source, collaborative web-GIS based learning platform, and is adapted for students in learning and understanding of environmental risk systems with a focus on geohazards and risk. This platform is particularly

5 aimed to apply in some exercises of the "environmental risk" and "advanced quantitative risk and vulnerability" courses of the Bachelor and Master of Sciences programs in the Faculty of Geosciences and Environment. The exercises of the courses are usually carried out individually by students in a paper-based manner, for example, an exercise for risk calculation of the affected buildings in a given area exposed to an event of debris flows. Beyond this conventional approach, with the aid of the RISKGIS's specific modules, exercises are taken place throughout the semesters on a web-GIS platform. This allows

10 students to visualize, interrogate and edit spatial data not only for risk calculation individually but also for working collaboratively in groups to propose and evaluate different risk reduction solutions using cost-benefit and multi-criteria evaluation methods integrated in the learning platform. Following in this paper, we present the context and framework of the teaching project in Sect. 2. Section 3 further presents the background framework and methods of the RISKGIS learning platform. In Sect. 4, different scenarios carried out with students using RISKGIS are described along with a discussion of

15 collected feedback results from students. Finally, we conclude the paper with reflection on the achieved outcomes and potential perspectives of the presented learning platform.

\section{Context and framework of the project}

The learning platform for students is proposed and designed, based on open-source modules and web-GIS applications developed within previous research works of authors (Aye et al., 2016a; Aye et al., 2016b; Olyazadeh et al., 2016) and the

20 experiences of testing a prototype collaborative platform with master students during a course on risk communication at the University of Lausanne in April 2015 (Aye et al., 2016c). In this exercise, students played the roles of different risk management stakeholders, and feedback was collected from them on different aspects of the exercise and platform. One of the aspects is whether students would like to do other exercises with such kind of interactive tools, and favourable feedback were achieved for students with experience in GIS. This serves as one of the needs why the RISKGIS platform is introduced

25 to teaching and learning in risk management of geohazards, by adapting existing approaches to the ones used in Switzerland, which are relevant to environmental risk (120-160 students) and advanced quantitative risk and vulnerability (10-15 students) courses of the University of Lausanne. The environmental risk course sets the goal to introduce environmental risks and their implications on the society from a quantitative viewpoint, while the advanced quantitative risk and vulnerability course is dedicated to the in-depth understanding of risk notions for a thorough risk calculation of natural hazards and it presents methods of Swiss Confederation among others including expert approaches such as impact-probability matrices. 
Nat. Hazards Earth Syst. Sci. Discuss., doi:10.5194/nhess-2017-85, 2017

Manuscript under review for journal Nat. Hazards Earth Syst. Sci.

Discussion started: 1 March 2017

(c) Author(s) 2017. CC-BY 3.0 License.

A large number of students follow the environmental risk course, and therefore, it is difficult to carry out a personalized follow-up of the exercises and to evaluate the level of understanding of the students. Besides, in risk analysis, solutions are often not unique and have to be discussed during the corrections, and as students, feedback on the proposed solutions is expected of teachers. Since the analysis of environmental risk is very much related to spatiality, it is difficult to deal with

5 realistic, generally large and complex, case during a course. Hence, until now, the solution was to deal with synthetic cases, which are sometimes too simplistic. In addition, the time spent to perform calculation by hand leaves little room for analysis of the results, which is furthermore less interesting with synthetic cases. Therefore, with this new web-GIS platform, real events of natural disasters can be used as case studies, greatly facilitating the management of spatial data and numerical calculation part. Students can also change different parameters of the calculation process to create various risk scenarios, and

10 this provides more room for the analysis and understanding of different outcomes. Moreover, with specific functionalities and modules of the learning platform, students can learn an overview of the risk management framework, starting from the risk analysis to the decision making process, like experts in real world with hand-on exercises.

\subsection{Envisaged pedagogical scenarios}

The aim is to create progressive learning, starting with risk calculation and ending with risk management. Some steps can be 15 carried out "by hand", however, others require the use of the web-GIS platform for centralized sharing of data and results, covering a larger geographical area. The use of this new technique permits to go further in the understanding and the assimilation of the issues, the proposition and the discussion of the solutions. Currently, students use GIS in several courses. GIS software is installed locally in computer rooms. These programs allow the display of geographic data and offer the possibility to carry out numerous processing (mappings, queries, calculations, etc.). Nevertheless, they are sometimes

20 complex to use and they do not allow a common (centralized) sharing of solutions. In parallel to traditional GIS, web-GIS tools have been developed, but only simple operations are usually allowed for most of the times (visualization of data and simple queries) via a web browser. The web portals of the cantons (www.geo.vd.ch) and confederation (www.map.geo.admin.ch) belong to this category, and some have been developed to facilitate education (EBIBALPIN, 2015; Tectonics, 2015). Therefore, the development of a new interactive web-GIS platform (RISKGIS) for teaching would

25 enable students not only to easily visualize data but also to perform operations (computation, introduction and edition of spatial data, simulations, etc.), and to save data in a central database. Students can connect to the platform with an individual account and see different interfaces/functionalities depending on their roles and exercises. The platform does not require any local installation or license, and can be freely accessible through a simple web-browser.

30 Three possible scenarios (exercises) are defined, built on the workflow of risk management framework (Fig. 1). The first scenario is to learn how to use the web-GIS platform with a simple risk calculation on an individual basis. The second scenario is to develop a risk reduction strategy by carrying out risk calculation (before and after consideration of measures), to carry out a simple cost-benefit calculation of the proposed strategy, and to confront it with others. This is a group work 
Nat. Hazards Earth Syst. Sci. Discuss., doi:10.5194/nhess-2017-85, 2017

Manuscript under review for journal Nat. Hazards Earth Syst. Sci.

Discussion started: 1 March 2017

(c) Author(s) 2017. CC-BY 3.0 License.
Natural Hazards

and Earth System

Sciences

Discussions

(c) $\underset{\mathrm{BY}}{(i)}$

exercise and each group is asked to submit a group report with an explanation and justification of their choices and results. The third scenario focuses on the importance of different actors, agendas and interests in group decision-making. It adds an additional component, Multi-Criteria Analysis (MCA), for selection of different risk reduction strategies by considering preferences of involved actors on different criteria. In this scenario, students play roles of different actors (such as geologists,

5 planners, environmental associations, mayor and population) in groups, and final decision is taken in a participative manner through discussion in the classroom. All scenarios use real events of natural disasters as case studies. The scenarios are then complemented with test quizzes and different (online) questionnaires to evaluate the learnt aspects on risk management, exercise and platform for improvements. The learning workflow of the RISKGIS platform including methods used is presented later in Sect. 3, and further detailed on the structure, content and results of scenarios (exercises) carried out with students are then described and discussed in Sect. 4.

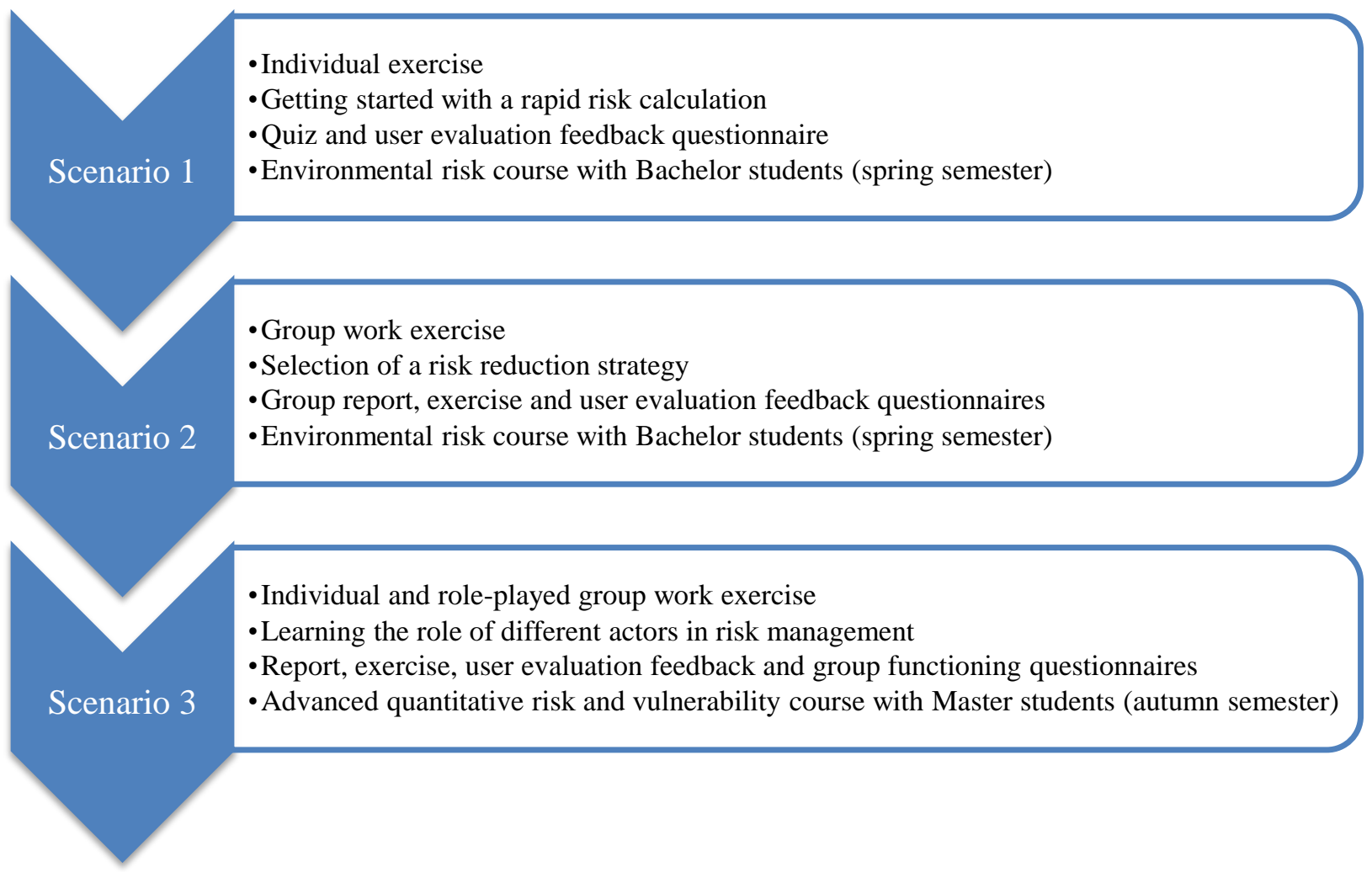

Figure 1: Illustration of three scenarios based on different stages of risk management.

\subsection{Pedagogical added values and improved learning experience}

15 RISKGIS brings the pedagogical added values such as the possibility to propose, discuss and compare different solutions of a problem during the courses as well as providing teachers with a better feedback on the students' level of understanding, 
Nat. Hazards Earth Syst. Sci. Discuss., doi:10.5194/nhess-2017-85, 2017

Natural Hazards

Manuscript under review for journal Nat. Hazards Earth Syst. Sci.

Discussion started: 1 March 2017

and Earth System

Sciences

(C) Author(s) 2017. CC-BY 3.0 License.

Discussions

(c) (i)

considering that the classroom is equipped with a reduced number of assistants at the institute. Besides, with RISKGIS, it has become possible to do exercises with more illustrative examples (such as real cases with no longer synthetic cases), putting students in an active mode which leads them out of a certain passivity of directed synthetic exercises. In addition, the confrontation of different scenarios and the discussion of the issues result in an in-depth learning of the concepts dealt within

5 the concerned courses in a much more effective way than at present.

Four important aspects can be highlighted in improving the learning experience of students through the use of RISKGIS: working on a concrete situation (the real case study), analysing it (calculation on the platform and debriefing in groups), generalizing of other possible situations (collective discussion with the teacher), and then experimenting these conclusions with new situations (several case studies are developed). This reflects the four moments of experiential learning, according to Kolb (1984), which allows to develop an in-depth learning of the concepts and skills analysed. Specifically, the following learning strategies are considered to develop experiential learning for students:

- The actual case study permits to illustrate the activities carried out by students, by giving them a little more sense and allowing them to make comparisons with reality.

- The discussions between students and the teacher make it possible to confront different points of view. Indeed, students can be able to decentre their own answers and benefit from the ideas of their colleagues and the teacher. The discussions also promote students to involve more actively, and thus, support their learning.

- The different reflective moments encourage students to have a look back on their work and to analyse their experiences in depth during the various activities.

- The Jigsaw allows students to develop expertise concerning the importance of different actors, agendas and interests in decision making. This activity demands the involvement of the students since they are responsible for capturing a role (theme) and then realizing it in different groups. In addition, feedback given from and between peers can strengthen and support their understanding.

- The visualization of risk situations using web-GIS throughout the world (such as real situations in Switzerland and the Alps for debris flows, the Haiti earthquake or the analysis of destructions due to typhoon Haiyan) allows to better understand risk analysis by anchoring to real cases.

\section{Background framework and methods}

The structure of the RISKGIS learning environment (Fig. 2) is based on two main components of risk management framework: risk analysis (estimation) and risk reduction (treatment). Risk estimation is defined as "the process of deriving a measure of the probability and severity of loss to the elements at risk by the integration of hazard and consequence analysis" (Crozier and Glade, 2005), and this can be performed quantitatively or qualitatively, depending on the study scale, data availability and aims of the analysis (Aye et al., 2016a). In this paper and developed learning framework, we apply risk 
Nat. Hazards Earth Syst. Sci. Discuss., doi:10.5194/nhess-2017-85, 2017

Manuscript under review for journal Nat. Hazards Earth Syst. Sci.

Discussion started: 1 March 2017

(c) Author(s) 2017. CC-BY 3.0 License.

(c) (i)

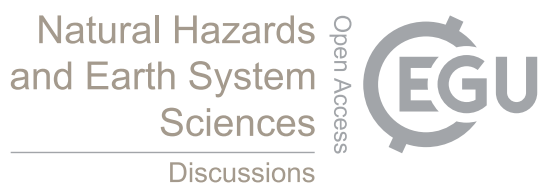

concepts and calculation approaches used in Switzerland (Bründl et al., 2009; EconoMe, 2015; Valdorisk, 2015). The outcomes of this process serve as an important input for decision making in risk management, depending on whether risks are tolerable or intolerable. Risk treatment is a process for risk modification and involves the selection and implementation of one or more options (Crozier and Glade, 2005). For students, within the RISKGIS learning environment, the focus is

5 placed on preparedness (and prevention) phase of Integrated Risk Management (IRM) cycle before an event is occurred. There are many options (alternatives) which can be applied in order to reduce the risk based on factors contributing to risk, for example, modifying the impacts of affected elements by reducing their vulnerability or reducing the intensity of the hazard through the implementation of some structural control measures in the area. This IRM approach requires a combination of measures for risk reduction (Holub and Hubl, 2008), and therefore, there is a need for coordinated efforts

10 between responsible authorities and organizations in selection of efficient and effective measures (De Marchi and Scolobig, 2012; Aye et al., 2016b). Consequently, this learning platform is designed in a collaborative manner so that students can reflect and learn this important issue of risk management in reality. Besides, through role playing, students can think and reflect content in a real world context beyond the classroom setting. For example, according to a mayor or a responsible actor's prioritization on different decision criteria, what is the most favourable alternative solution in selection of risk

15 reduction strategies? 
Nat. Hazards Earth Syst. Sci. Discuss., doi:10.5194/nhess-2017-85, 2017

Manuscript under review for journal Nat. Hazards Earth Syst. Sci.

Discussion started: 1 March 2017

(c) Author(s) 2017. CC-BY 3.0 License.

(c) (i)

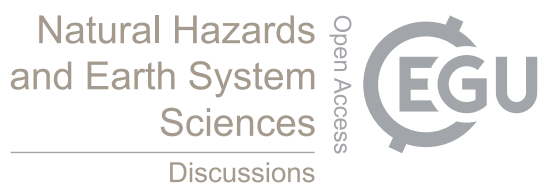

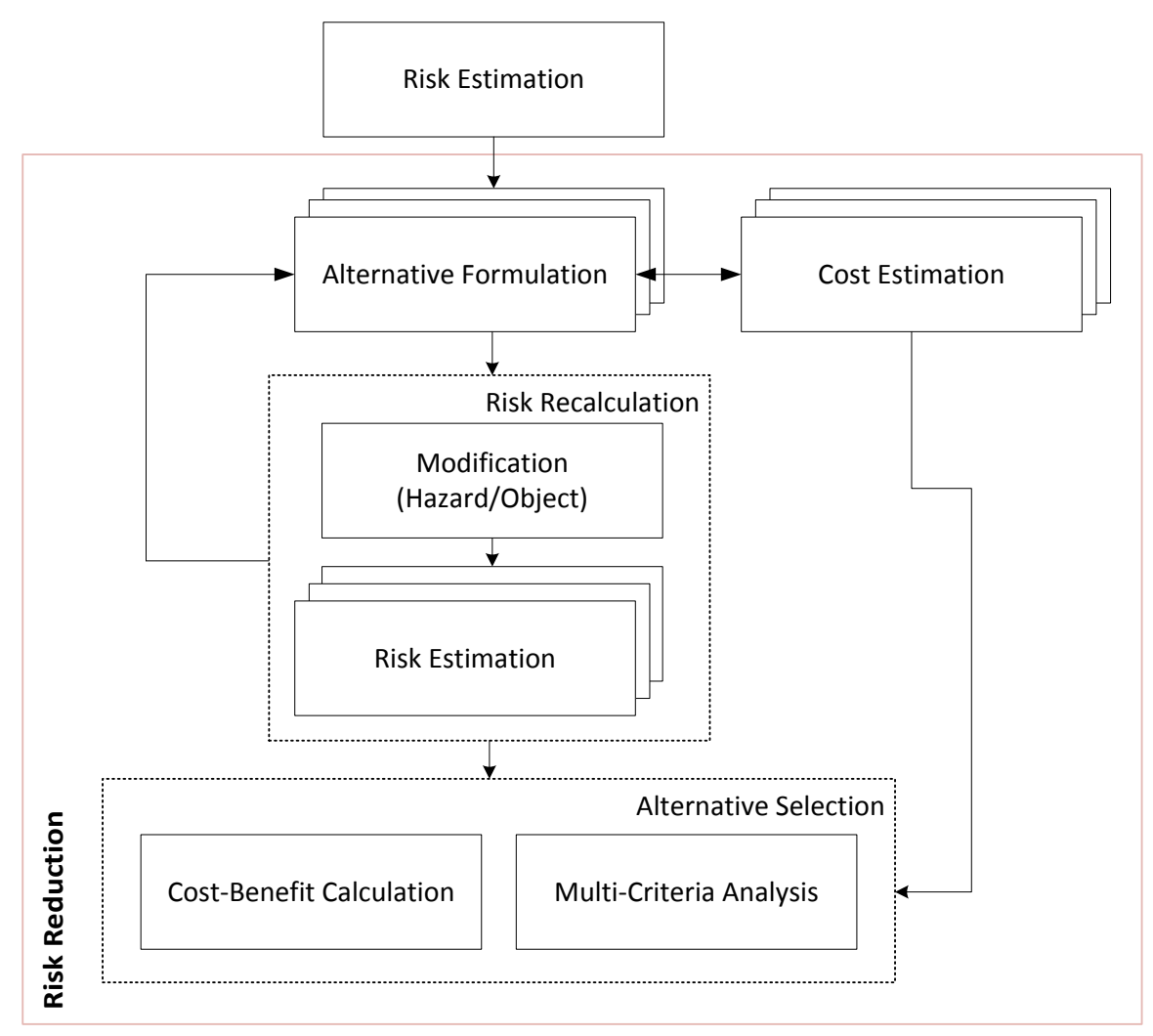

Figure 2: Workflow of the RISKGIS learning environment and its components.

The workflow of the learning platform is organized in six steps as follows: 1) risk estimation; 2) formulation of alternatives;

3) cost estimation of alternatives; 4) recalculation of risk after alternatives; 5) cost-benefit calculation of alternatives; and 6)

5 selection of alternatives with Multi-Criteria Analysis.

\section{Step 1: Risk estimation}

In this step, risk is estimated by using «Risk Calculator» tool of the RISKGIS learning platform, where default parameters (i.e. hazard, building and vulnerability parameters) can be changed to create different risk scenarios and analyse the variation in risk. In the learning platform, the risk of the buildings $R_{i, j}$ (CHF/year) is calculated for each affected building $i$ of the

10 whole building layer and for a hazard layer $j$ as follows (modified from EconoMe, 2015; Valdorisk, 2015):

$R_{i, j}=f_{j} \times \operatorname{Pr} A_{j} \times V_{i, j} \times W_{i}$, 
Nat. Hazards Earth Syst. Sci. Discuss., doi:10.5194/nhess-2017-85, 2017

Manuscript under review for journal Nat. Hazards Earth Syst. Sci.

Discussion started: 1 March 2017

(c) Author(s) 2017. CC-BY 3.0 License.

(c) (i)

where $f_{j}$ is the frequency (inverse of the return period $T$ ) of the hazard $j$; $\operatorname{Pr} A_{j}$ is the probability of spatial occurrence of the hazard $j ; V_{i, j}$ is the respective vulnerability value of the building $i$ depending on the intensity class of the hazard $j$ in which it is exposed; and $W_{i}$ is the monetary value of the building $i$.

5 For the monetarized collective risk of persons (inside the buildings), $R_{i, j}$ (CHF/year) is calculated for each affected building $i$ of the whole building layer and for a hazard layer $j$ as follows (modified from Bründl et al., 2009 and EconoMe, 2015; Valdorisk, 2015):

$R_{i, j}=f_{j} \times \operatorname{Pr}_{j} \times \operatorname{Ppr}_{i} \times \lambda_{i, j} \times N_{i} \times 5000000 \mathrm{CHF}$,

where $f_{j}$ is the frequency (inverse of the return period $T$ ) of the hazard $j ; \operatorname{Pr} A_{j}$ is the probability of spatial occurrence of the

10 hazard $\mathrm{j} ; \mathrm{Ppr}_{i}$ is the probability of presence of persons in the building object $i$ (for example, 0.5 for a person who is present in the building for 12 hours per day); $\lambda_{i, j}$ is the lethality of persons in the building object $i$ for the considered hazard $j$; $N_{i}$ is the number of persons in the building object $i$; and $5000000 \mathrm{CHF}$ is the marginal cost that the society is willing to pay to avoid the death.

15 For the individual risk (death/year), it is calculated the same as Eq. (2), except the number of persons and the marginal cost of a person are not included (modified from Bründl et al., 2009 and EconoMe, 2015; Valdorisk, 2015):

$R_{i, j}=f_{j} \times \operatorname{Pr}_{j} \times \operatorname{Ppr}_{i} \times \lambda_{i, j} \times 1$,

where $f_{j}$ is the frequency (inverse of the return period $T$ ) of the hazard $j$; $\operatorname{Pr} A_{j}$ is the probability of spatial occurrence of the hazard $\mathrm{j} ; \mathrm{Ppr}_{i}$ is the probability of presence of the person in the building object $i$ (for example, 0.5 for a person who is

20 present in the building for 12 hours per day); $\lambda_{i, j}$ is the lethality of the person in the building object $i$ for the considered hazard $j$; and 1 is a person.

\section{Step 2: Formulation of alternatives (design of preliminary measures)}

After identifying areas at risk, the next step is to formulate possible alternatives based on the outcomes of the previous step. A combination of risk reduction measures is possible within an "alternative" (both structural and/or non-structural measures). Potential risks can be reduced based on the contributing factors such as hazard, exposure of elements-at-risk and vulnerability through the implementation of effective risk management strategies. Structural measures are defined as "any physical construction to reduce or avoid possible impacts of hazards, or application of engineering techniques to achieve hazard-resistance and resilience in structures or systems" (UNISDR, p. 28). Non-structural measures are "any measures not involving physical construction that uses knowledge, practice or agreement to reduce risks and impacts, in particular through policies and laws, public awareness raising, training and education" (UNISDR, p. 28). Here, students can design/propose 
Nat. Hazards Earth Syst. Sci. Discuss., doi:10.5194/nhess-2017-85, 2017

Manuscript under review for journal Nat. Hazards Earth Syst. Sci.

Discussion started: 1 March 2017

(c) Author(s) 2017. CC-BY 3.0 License.
Natural Hazards

and Earth System

Sciences

Discussions

(c) (i)

alternatives through the web-GIS mapping interface using available sketching tools and measures in the learning platform. Examples of measures are dike, tunnel, stabilization works, protection nets against rock falls and debris flows, reforestation, maintenance of the protection forests and so on.

\section{Step 3: Cost estimation of alternatives}

5 After identifying possible risk reduction measures in the affected area, the potential cost of measures is estimated for their proposed alternatives. The annual cost of the measure is calculated as follows (Bründl et al., 2011):

$K_{t o t}=K_{b}+K_{u}+K_{r}+\frac{\left(I_{0}-L_{n}\right)}{n}+\frac{\left(I_{0}+L_{n}\right)}{2} \times \frac{p}{100}$,

where $K_{b}$ is the operating cost; $K_{u}$ is the maintenance cost; $K_{r}$ is the repairs cost; $I_{0}$ is the initial investment cost; $L_{n}$ is the residual value after $n$ years (in general, $L_{n}=0$ ); and $p$ is the interest rate fixed at $2 \%$. Within the learning platform, measures

10 and associated default parameter values for cost estimation are obtained from EconoMe (OFEV, 2016) and Valdorisk (Valdorisk, 2015). Depending on the "mode" of the cost estimation process (auto or manual), these default parameters can be changed accordingly by users of the RISKGIS platform.

\section{Step 4: Risk re-calculation after alternatives}

The next step is to re-calculate risk (in a preliminary manner) after the consideration of an alternative to know how much

15 risk has been reduced in the affected area. In order to re-calculate risk, students can create new layers of hazard and/or building, depending on their designed alternative. For example, if an alternative includes measures which modify (or reduce) the intensity level and spatial location (polygon shape) of hazard, then a new hazard layer is created and modified accordingly based on the original hazard layer. Or if an alternative considers measures which affect the location of buildings (for example, relocation of houses), a new building layer can be created to remove relocated houses from the original

20 building layer. If an alternative includes measures which change the vulnerability, then vulnerability parameters can be directly modified during the re-calculation of risk.

\section{Step 5: Cost-Benefit calculation}

As a final step of the selection process of alternatives, a cost-benefit report is prepared to compare the risk before and after the consideration of an alternative. For this purpose, the cost-benefit ratio is calculated in the learning platform as follows

25 (Bründl et al., 2011):

$$
\frac{N}{K_{\text {tot }}}=\frac{R(\text { before })-R(\text { after })}{K(j)}=\frac{R(v)}{K(j)}
$$


Nat. Hazards Earth Syst. Sci. Discuss., doi:10.5194/nhess-2017-85, 2017

Manuscript under review for journal Nat. Hazards Earth Syst. Sci.

Discussion started: 1 March 2017

(c) Author(s) 2017. CC-BY 3.0 License.
Natural Hazards

and Earth System

Sciences

Discussions

(c) $\underset{\mathrm{BY}}{(i)}$

where $\frac{N}{K_{t o t}}$ is the cost-benefit ratio of the measure or the combination of measures, and it is profitable if this ratio is $>=1$; $R(v)$ is the annual reduction of risk before and after the implementation of measures; and $K(j)$ is the annual cost of the planned alternative $j$ (protection measures).

\section{Step 6: Selection of alternatives with Multi-Criteria Analysis}

5 Going a step further in the decision making process and taking the advantage of the collaborative and centralized web-based environment, the RISKGIS learning platform integrates MCA approach for evaluation of alternatives based on various decision criteria. The decision making process can benefit from using MCA methods. These methods consider different alternatives with the aim of addressing trade-offs between them by including additional criteria (such as social and environmental) than the traditional cost-benefit criteria (Munda, 2004). Besides, these approaches allow to represent

10 conflicting views of involved actors and facilitate the decision making process (Kiker et al., 2005). In the learning platform, Compromise Programming (CP) method (Zeleny, 1973; Simonovic, 2010) is applied for ranking of alternatives. By means of distance, this method identifies the closest alternatives to the ideal solution, and this ideal solution is a vector of best values of evaluated decision criteria resulting from a payoff (or performance evaluation) matrix. This payoff matrix $A$ is an evaluation matrix of $m$ Alternatives against $n$ Criteria, and is represented as follows in Eq. (6):

$15 \quad A=\left[a_{i j}\right]=\left[\begin{array}{cccc}a_{11} & a_{12} & \ldots & a_{1 n} \\ a_{21} & a_{22} & \ldots & a_{2 n} \\ \ldots & \ldots & \ldots & \ldots \\ a_{m 1} & a_{m 2} & \ldots & a_{m n}\end{array}\right]$,

where $a_{i j}$ is the evaluation value of Alternative $i$ for Criteria $j ; m$ is the number of alternatives and $n$ is the number of criteria. The distance measure of an alternative $L_{p}(x)$ is "a function of the criteria values themselves, the relative importance of the various criteria to the decision makers $\left(\alpha_{i}\right)$, and the importance of the maximal deviation from the ideal solution $(p)$ " as shown in following Eq. (7) (Simonovic, 2010, p. 274):

$L_{p}\left(x_{p}^{*}\right)=\operatorname{Min}\left\{L_{p}(x)=\left[\sum_{i=1}^{r} \alpha_{i}^{p}\left(\frac{A_{i}^{*}-A_{i}(x)}{A_{i}^{*}-A_{i}^{* *}}\right)^{p}\right]^{\frac{1}{p}}\right\}$,

where $A_{i}(x)$ is the evaluation value of an alternative $x$ for the considered criterion $i$; $A^{*}$ is the maximum function value of the considered criterion; $A^{* *}$ is the minimum function value of the considered criterion; $\alpha_{i}$ is the weight (relative importance) of the considered criterion; $p$ is the importance of the maximal deviation from the idea solution and $r$ is the 
Nat. Hazards Earth Syst. Sci. Discuss., doi:10.5194/nhess-2017-85, 2017

Manuscript under review for journal Nat. Hazards Earth Syst. Sci.

Discussion started: 1 March 2017

(c) Author(s) 2017. CC-BY 3.0 License.

number of criteria. The alternative with the minimum distance value to the ideal situation is considered as the "best compromise solution".

\section{Scenarios with students using RISKGIS learning platform}

\subsection{Scenario 1: Getting started with RISKGIS}

5 The purpose of this scenario is to introduce the RISKGIS platform to students in learning and understanding of risk estimation process with a case study. This exercise was carried out with Bachelor students of the environmental risk course during the exercise session on 14 March 2016. The exercise is composed of two stages: exploration of available maps and tools, and risk estimation. Necessary data and maps are prepared and uploaded to the learning platform by teachers and assistants beforehand. Before starting the exercise, the short introduction of the platform and the task was presented to

10 students. The tutorial documentation and a step-by-step video demonstration are also made available. Then, by following the given step-by-step instructions of the tutorial and data of the study area, each student logs in to the platform and performs a simple risk calculation. At the end of the exercise, in the Moodle (www.moodle.org), students are asked to answer a quiz to check whether they understood the purposes of different functionalities in the platform as well as a feedback questionnaire to obtain the user evaluation feedback on the platform. The access to the platform, test quiz and feedback questionnaire were

15 opened for two weeks starting from the day of the exercise. Out of the registered 82 students, 30 students answered the quiz and 23 students responded the feedback questionnaire. The results are presented below in Sect. 4.1.3.

\subsubsection{Study area}

An example study area of the exercise is in Jomsom town located in the mountainous area of Nepal at an altitude of about $2700 \mathrm{~m}$ in Mustang District, which is a famous touristic area known for hikers in Himalayas. Figure 3 shows an overview of

20 areas around Jomsom in Mustang District, where landslides affected some agricultural fields located in the valley (left) and one of the schools in the area (right). Jomsom was slightly affected by the 2015 earthquake (7.8 Magnitude, VIII of Modified Mercalli Intensity Scale) and many buildings were damaged, however, no injuries were reported in the town (Nelson News, 2015; SMH, 2015). We chose it as a study area not only because it is a remote area affected by earthquake but also because of the availability of OpenStreetMap data. According to the Global Seismic Hazard Map (Giardini et al., 2003), the seismic

25 hazard of this area is estimated to be severe showing Peak Ground Acceleration (pga) of $0.368 \mathrm{~g}$ (i.e. VIII Scale of MMI) with $10 \%$ probability of exceedance in 50 years, corresponding to a return period of 475 years. In this exercise, we imagine that if this area may be affected by location site effects (such as amplifications of shaking) targeting the centre of Jomsom, then what would be the risk for buildings and people? For data inputs, buildings are extracted from OpenStreetMap (www.openstreetmap.org) and the earthquake intensity map is designed based on the geological characteristics and DEM 30 (Digital Elevation Model) of the area by an expert. The default vulnerability values for damages and death rates are derived 
Nat. Hazards Earth Syst. Sci. Discuss., doi:10.5194/nhess-2017-85, 2017

Manuscript under review for journal Nat. Hazards Earth Syst. Sci.

Discussion started: 1 March 2017

(C) Author(s) 2017. CC-BY 3.0 License.
Natural Hazards

and Earth System

Sciences

Discussions

(c) $\underset{\mathrm{BY}}{(\mathrm{P}}$

from ATC-13 report (Rojahn and Sharpe, 1985). Here, we assume that buildings in Jomsom are unreinforced masonry houses, and the casualty rates are tied to the damage states of the houses.
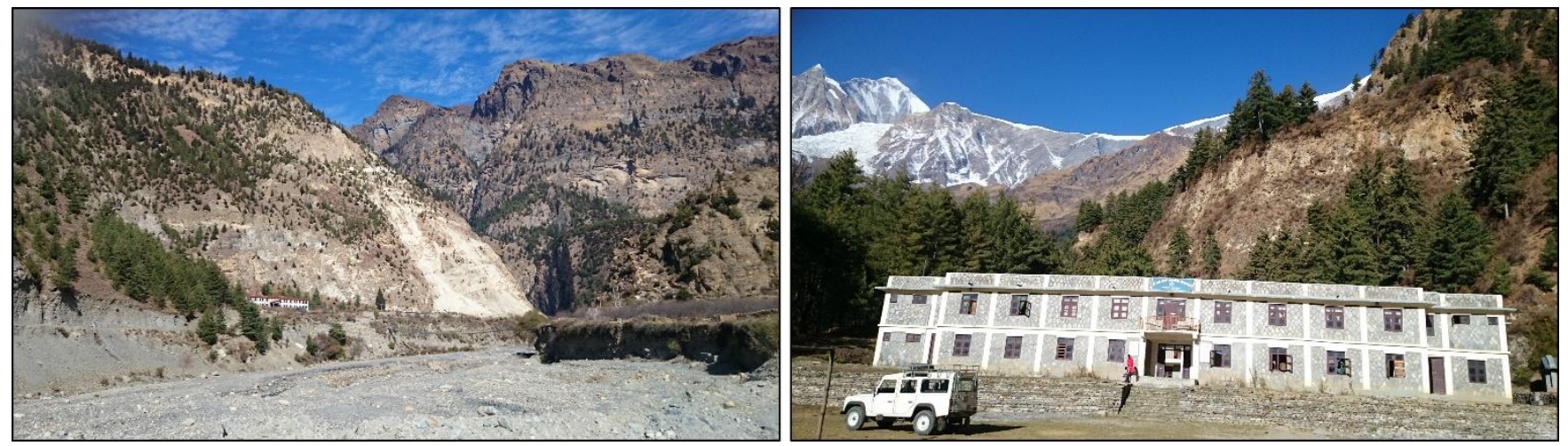

5 Figure 3: Photos of the areas around Jomsom in Mustang District (Nepal), showing landslides which affected some agricultural fields located in the valley (left) and one of the schools in the area (right).

\subsubsection{Stages of the scenario}

In this first stage of the exercise, students are asked to start with adding layers of building and earthquake intensity maps to the web-GIS map interface of the learning platform. For this purpose, building and intensity maps are uploaded into the

10 platform beforehand. The task of this stage is for students to identify and visualize the potential Jomsom areas affected by the earthquake by simply overlaying these two layers and visualizing the buildings which are being touched by different levels of earthquake intensity. Besides, to learn basic components of GIS, students are also asked to explore available tools in the platform such as adding and removing layers to and from the map panel, zoom and feature information tools, location search box and so on. In the second stage, students estimate risk of buildings and humans for the whole study area by using

15 the «Risk Calculator» tool of the RISKGIS learning platform (see Fig. 8 for an example illustration, however, only "Risk Analysis" menu is visible and enabled in this exercise). Here, students can change the default building information such as price per square meter (USD), number and exposition of people (hours) as well as vulnerability information (i.e. degree of damages and casualties in percentage in relation to a certain level of intensity and damage state) to analyse the variation in risk depending on the input parameters. For this risk calculation, a return period of 1 year is used in this exercise. The risk

20 results could therefore be divided by the corresponding return period (for example, 475 years) to obtain risk of a certain return period.

\subsubsection{Results and discussion}

For the test quiz in Moodle, 10 questions were asked to students concerning different functions and interfaces of the platform, mainly for the risk calculation module such as definition of risk, the intensity level which has the highest risk per

25 year, number of buildings exposed to the earthquake, and so on. Out of 30 students' answers, the global average score was 9.39 out of 10 notes (maximum). This means most of the students learned and understood correctly of how the platform 
Nat. Hazards Earth Syst. Sci. Discuss., doi:10.5194/nhess-2017-85, 2017

Manuscript under review for journal Nat. Hazards Earth Syst. Sci.

Discussion started: 1 March 2017

(c) Author(s) 2017. CC-BY 3.0 License.

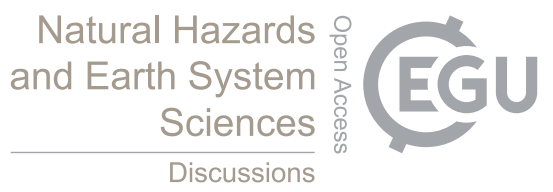

(c) (1)

functions. The following Fig. 4 shows the total number of students respective to the interval of notes ( 1 note is given for each question and a total of 10 questions were asked).

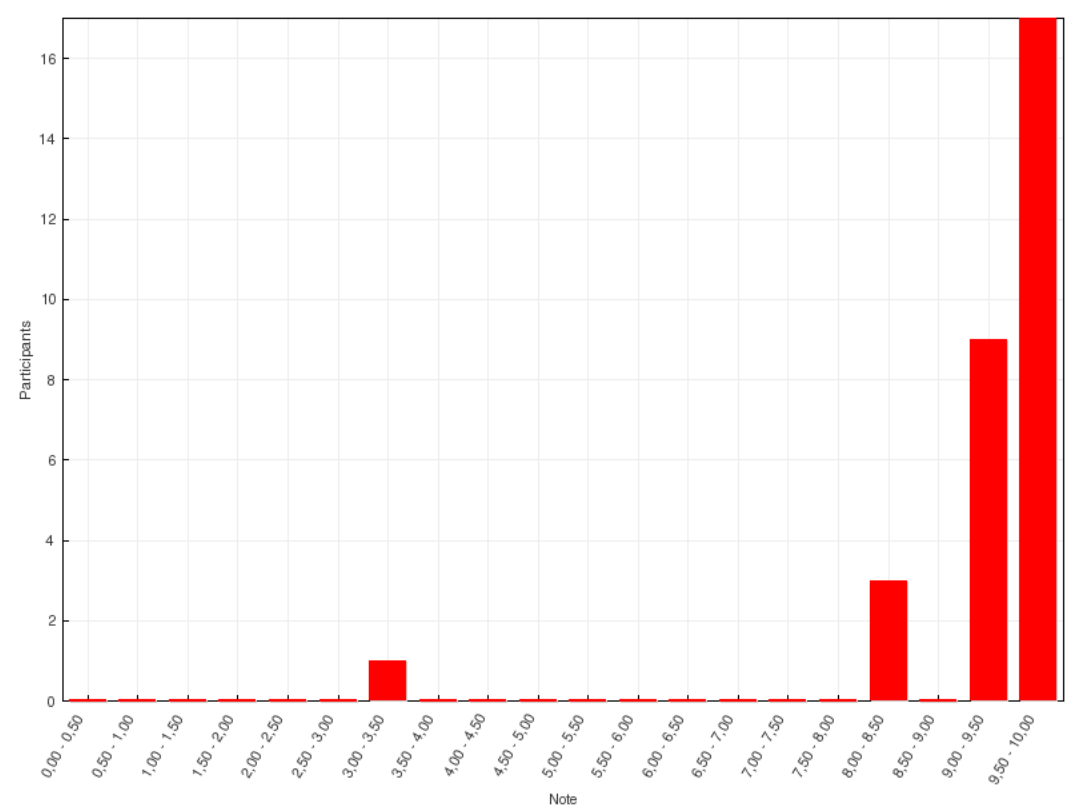

Figure 4: Number of students with respective notes (1 note is given for each question and a total of 10 questions were asked).

5 The user evaluation feedback questionnaire is composed of different sections: 1) purpose of the platform (in a few words); 2) a simple 5-point, ten-item question of SUS (System Usability Scale) to obtain a global view of the usability assessment (Brooke, 1996); 3) an overall satisfaction score (on a scale of 1-10) of using the platform; and 4) aspects of the platform to be improved and supplementary suggestions/comments. Out of 23 responses (Fig. 5), we achieved an average SUS score of $68.41 / 100$ and the overall satisfaction of the platform was 7.13/10. The ten items of the SUS (Q1-Q10) are listed as follows, representing positive and negative items:

Q1. I think that I would like to use this system frequently.

Q2. I found the system unnecessarily complex.

Q3. I thought the system was easy to use.

Q4. I think that I would need the support of a technical person to be able to use this system.

15 Q5. I found the various functions in this system were well integrated.

Q6. I thought there was too much inconsistency in this system.

Q7. I would imagine that most people would learn to use this system very quickly.

Q8. I found the system very cumbersome to use.

Q9. I felt very confident using the system.

Q10. I needed to learn a lot of things before I could get going with this system. 
Nat. Hazards Earth Syst. Sci. Discuss., doi:10.5194/nhess-2017-85, 2017

Manuscript under review for journal Nat. Hazards Earth Syst. Sci.

Discussion started: 1 March 2017

(c) Author(s) 2017. CC-BY 3.0 License.

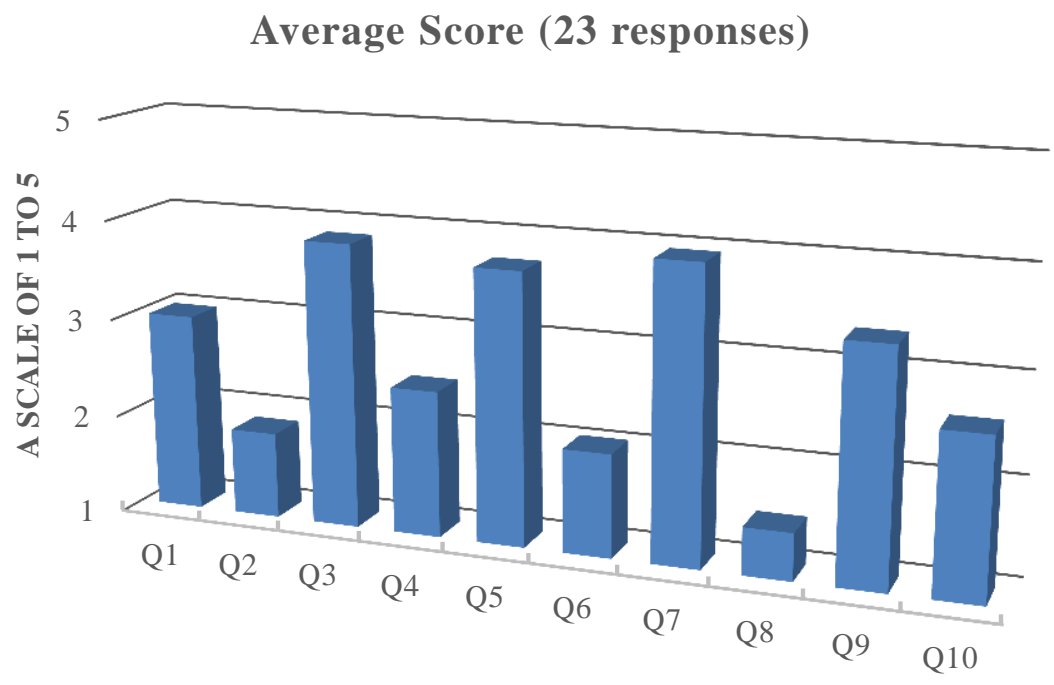

Figure 5: Feedback on the platform (overall) based on a 5-point, ten-item scale of SUS. The answers were rated by a scale of 1 to 5 (Strongly disagree to strongly agree).

To sum up the feedback of students on written sections, students mentioned the purpose of the platform is to evaluate and

5 model risk (materials and humans) of a study zone easily and rapidly in function of pre-defined parameters and existing data, helping to better understand and analyse risks, and to find more effective risk reduction solutions based on outcomes. It was also mentioned that, thanks to the computer power, it is possible to simply modify numerous variables and consider multiple scenarios of risk, by making the process simplified and more accessible to the quantification and representation of different types of risks. Regarding the aspects to be improved, some students found the platform very interesting and easy to use, and

10 that it is difficult to make a criticism because the platform looks very much like other software that they are already using, while some mentioned that usage of the platform on portable systems such as tablets and smart phones can be improved and that the attribute columns of the risk layer should be made clearer. It was also mentioned that being able to adjust the size of the window panels (i.e. Data view, legend and layers) would be helpful. For additional comments and suggestions, students stated to make a much longer and deeper exercise with the application as well as to create a good structure of saving output

15 layers in a more structured way, while they have also showed their interests of using it for other possible exercises with study areas in the Alps to better get an idea of the terrain. According to the responses, the purpose of the platform and exercise was well-understood by students, and favourable feedback were received on using the RISKGIS learning platform in doing this very first exercise with students.

\subsection{Scenario 2: Selection of a risk reduction strategy using RISKGIS}

20 The learning objective of this scenario is for students to develop a better understanding in risk management using the RISKGIS learning platform with a real case study (for example, debris flows event in Brienz, Switzerland). This second 
Nat. Hazards Earth Syst. Sci. Discuss., doi:10.5194/nhess-2017-85, 2017

Manuscript under review for journal Nat. Hazards Earth Syst. Sci.

Discussion started: 1 March 2017

(c) Author(s) 2017. CC-BY 3.0 License.

exercise was again performed with same Bachelor students of the environmental risk course during the course and exercise sessions on 18 April 2016. The structure of the exercise follows the workflow of the learning framework illustrated in Fig. 2 without the last MCA component. This exercise was carried out in small groups (no more than 5 students in each and students chose their group partners via Moodle), and a login account was created for each group so that results can be shared

5 and visualized within the same group. By following the given tutorial exercise and data of the study area, each group of students proposes its own alternatives (risk reduction measures) by carrying out risk calculation (before and after consideration of alternatives) and performs cost-benefit analysis of the proposed alternatives. To complete the exercise, students are required to submit via the Moodle platform: a group report on the obtained results, an exercise and a user evaluation feedback individually to evaluate the performance of the exercise and platform. The access to the platform,

10 submission of the group reports and feedback questionnaires were opened for three weeks. Out of the registered 85 students, 69 students participated and formed 15 groups. Before the deadline of the exercise, 14 groups submitted their reports, 55 and 52 students responded the exercise and user evaluation feedback questionnaires respectively. The results of students' feedback are presented and discussed in Sect. 4.2.3.

\subsubsection{Study area}

15 In this exercise, we study the village of Brienz located on the Shore of Brienz Lake in the canton of Bern, Switzerland (Fig. 6a). In 22-23 August 2005, after a long lasting rainfall (more than $300 \mathrm{~mm}$ in 3 days), landslides and debris flows occurred and caused extensive damage to this village (Fig. 6b). Approximately $70,000 \mathrm{~m}^{3}$ of debris was transported into a densely populated part of the village (PLANAT, 2016). Two people died, about 30 houses were damaged completely or partly, and 300 people were needed to be evacuated in a very short time. The total damage was over 30 million Swiss francs (Hitz and

20 Hahlen, 2014), and this event was one of the many disastrous events which occurred during August 2005 in the Bernese Oberland and the Swiss Alps. After this event, a flood prevention project was initiated and the designation of the protection works was inaugurated in August 2013, which involved costs of about 35 million Swiss francs (Haberle, 2014). In this exercise, we reconsider that this August 2005 event has just happened due to the prolonged rainfall in the area. Then, students try to answer questions such as risks of buildings and people in this area, measures to reduce risks and their cost effectiveness and so on. For the study data, buildings are extracted from OpenStreetMap and the debris flow intensity map (with a return period of 100 years) is derived based on the expert knowledge and hazard assessment carried out after August 2005 (Hitz and Hahlen, 2014). The default vulnerability values for damages and causalities are obtained from EconoMe (OFEV, 2016). Here, we consider that buildings in this study area fall into the category of individual houses, exclusively for the residential use (such as villas and chalets). 
Nat. Hazards Earth Syst. Sci. Discuss., doi:10.5194/nhess-2017-85, 2017

Manuscript under review for journal Nat. Hazards Earth Syst. Sci.

Discussion started: 1 March 2017

(c) Author(s) 2017. CC-BY 3.0 License.

\section{Natural Hazards

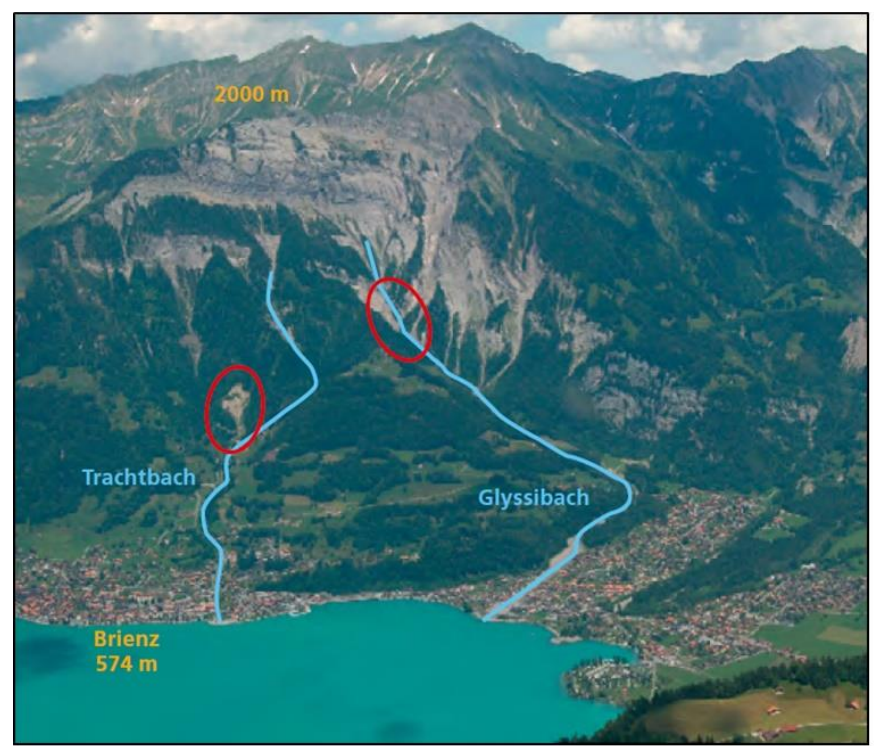

(a)

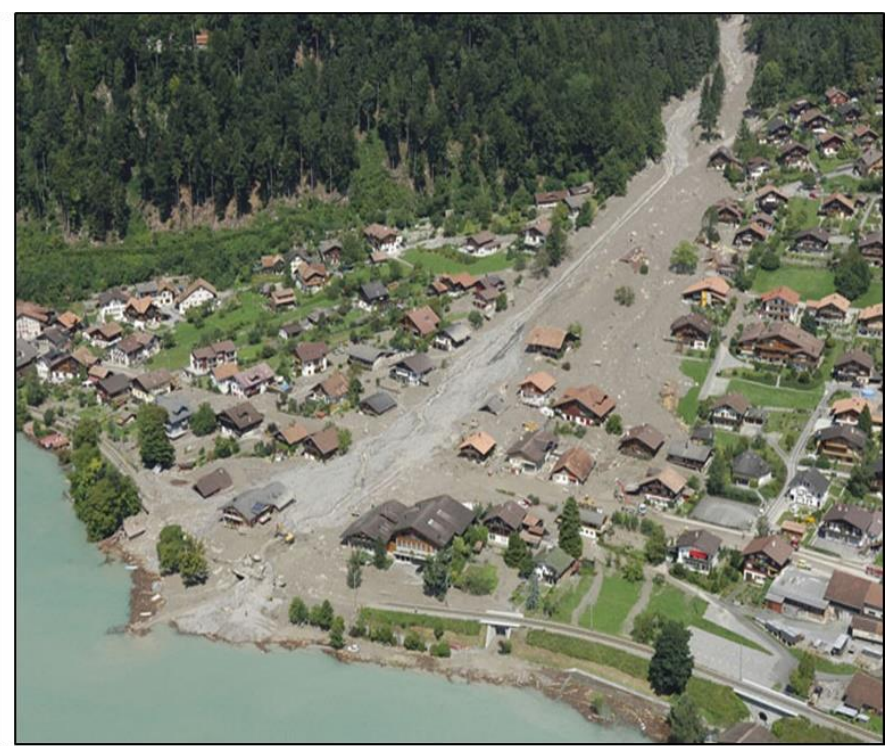

(b)

Figure 6: (a) Brienz with the two landslides (red) in the catchment areas of the Trachtbach and Glyssibach torrents (Source: Haeberle, 2014). (b) Debris flow event and its damages along Glyssibach, Brienz in August 2005 (Source: PLANAT, 2016).

\subsubsection{Stages of the scenario}

5 In this exercise (Fig. 7), each group of students is asked to submit a group report on the considered study area by answering the following questions with an explanation and justification of their choices and results:

- risks of buildings and people,

- needed measures to be placed in order to reduce risk,

- estimated cost of the proposed alternative,

- risks after the implementation of the proposed alternative, and

- profitability of the proposed alternative in terms of cost and benefit. 
Nat. Hazards Earth Syst. Sci. Discuss., doi:10.5194/nhess-2017-85, 2017

Manuscript under review for journal Nat. Hazards Earth Syst. Sci.

Discussion started: 1 March 2017

(c) Author(s) 2017. CC-BY 3.0 License.

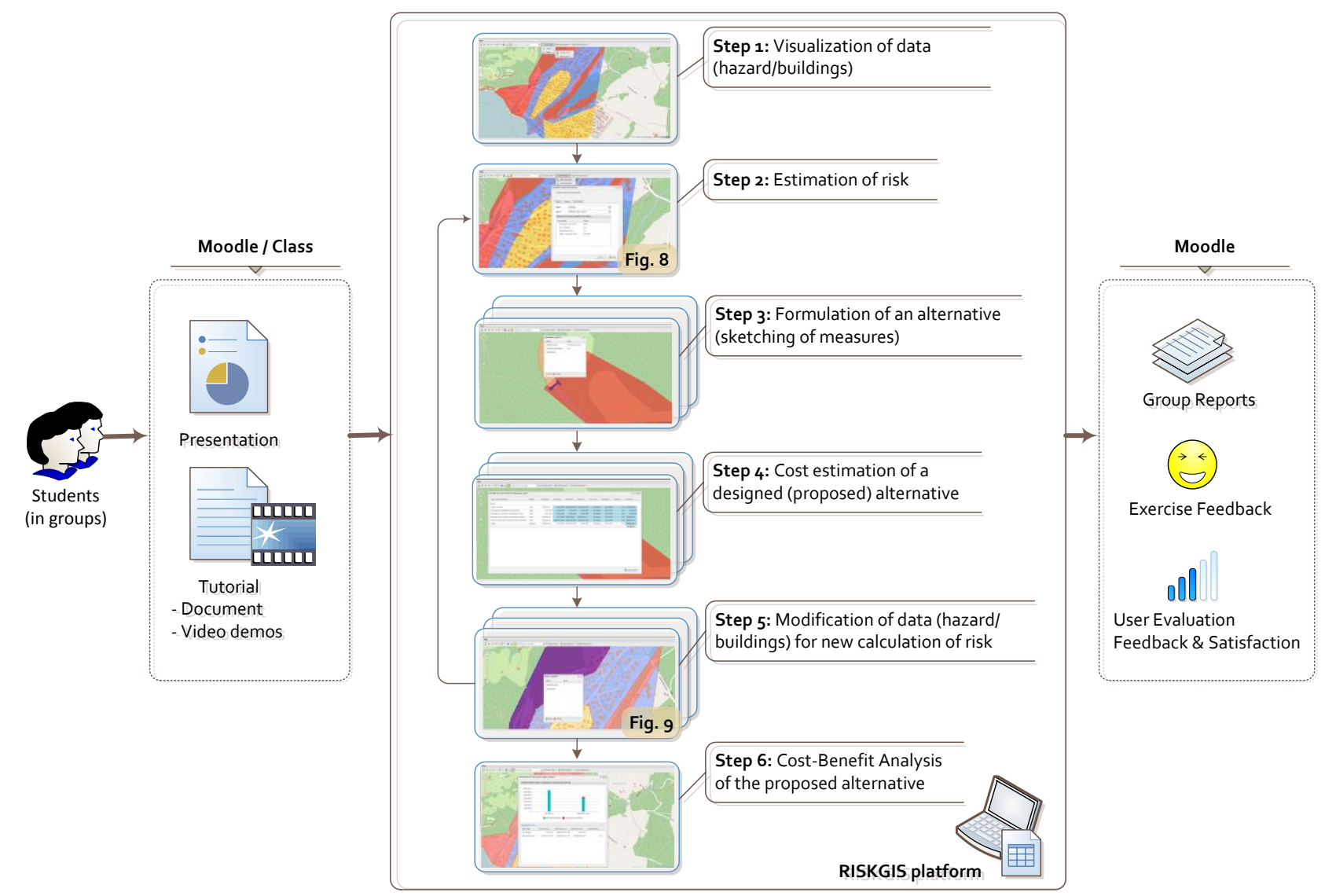

Figure 7: Structure of the exercise illustrating different steps of the exercise, in which students (in groups) use the RISKGIS and Moodle platforms for performing tasks and activities.

First of all, students get themselves familiarized with the study area by exploring available data (including building and

hazard intensity maps), identifying and visualizing the potential areas affected by debris flows. Then, students estimate risk by selecting necessary parameters of the «Risk Calculator» tool as shown in Fig. 8 to answer the first question of the exercise. In the next step 3, based on the outcomes of the risk estimation process, we ask each group to design and propose their own alternative to reduce risk in the area. Here, we define "alternative" as a combination of risk reduction measures, which could be both structural and/or non-structural measures. Students can design their alternatives based on the available measures in the learning platform and answer the question of why their proposed alternatives should be considered and implemented. After formulating measures, in the step 4, students calculate annual cost of their proposed alternatives by entering estimated values of different parameters as shown in Eq. (4). Then in the step 5, students re-calculate risk after consideration of their proposed alternatives by creating and modifying new hazard and/or building layers (Fig. 9), depending on the measures they considered for risk reduction. Finally in the last step, students generate a cost-benefit report by

15 selecting risk scenarios they calculated before and after the consideration of proposed alternatives, and answer the question of whether their proposed alternative is profitable based on the obtained cost-benefit ratio. 
Nat. Hazards Earth Syst. Sci. Discuss., doi:10.5194/nhess-2017-85, 2017

Manuscript under review for journal Nat. Hazards Earth Syst. Sci.

Discussion started: 1 March 2017

(c) Author(s) 2017. CC-BY 3.0 License.
Natural Hazards and Earth System Sciences

Discussions (c) (i)

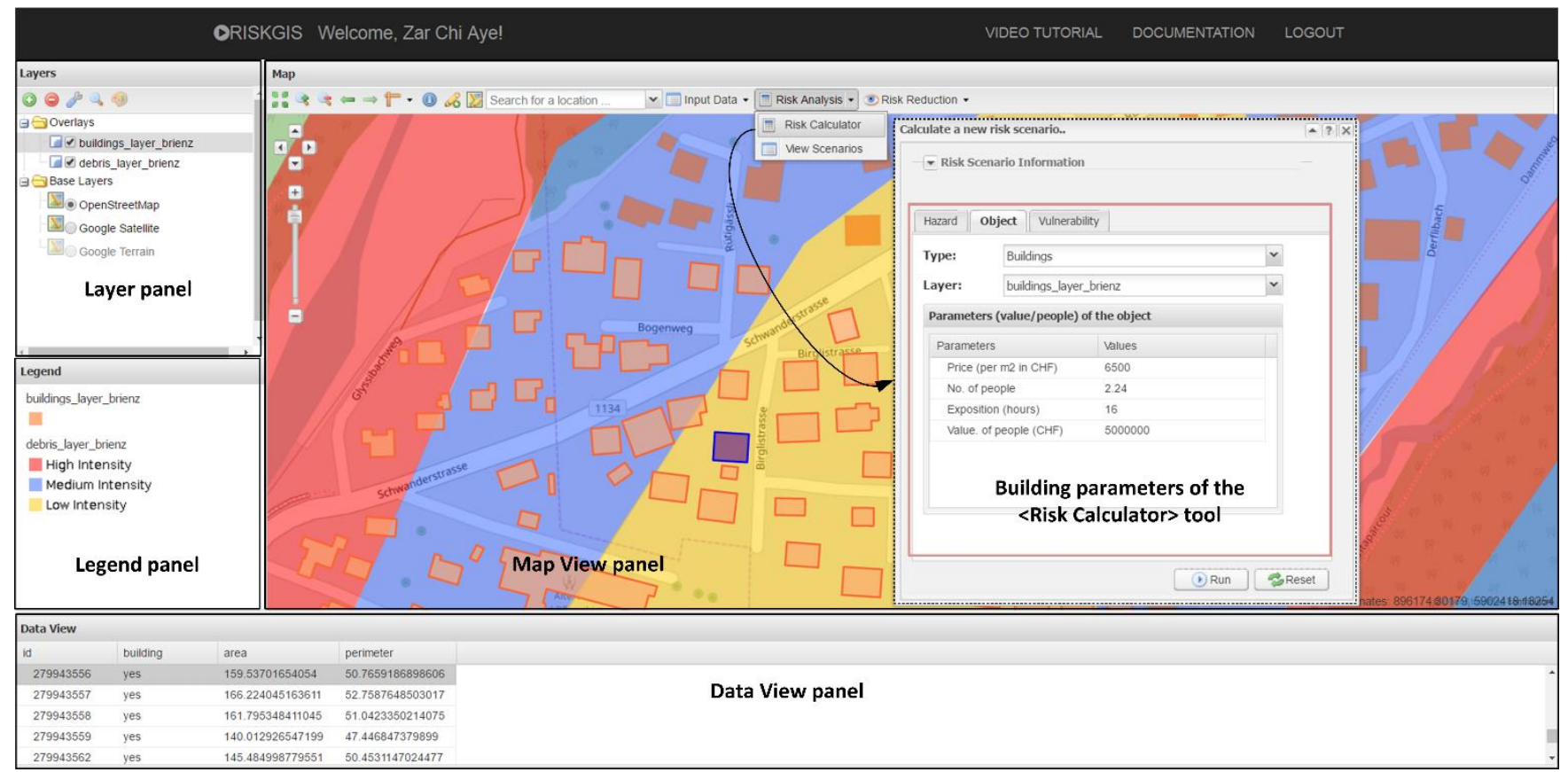

Figure 8: Illustration of the popup interface of the «Risk Calculator» tool for creation of a new risk scenario in the RISKGIS platform. This tool is accessible through "Risk Analysis" menu located on the top toolbar of the center map panel. "Input Data" menu contains tools to access input layers (such as hazard and building maps), while "Risk Reduction" menu is composed of tools to create new alternatives, calculate cost of alternatives, and generate cost-benefit report.

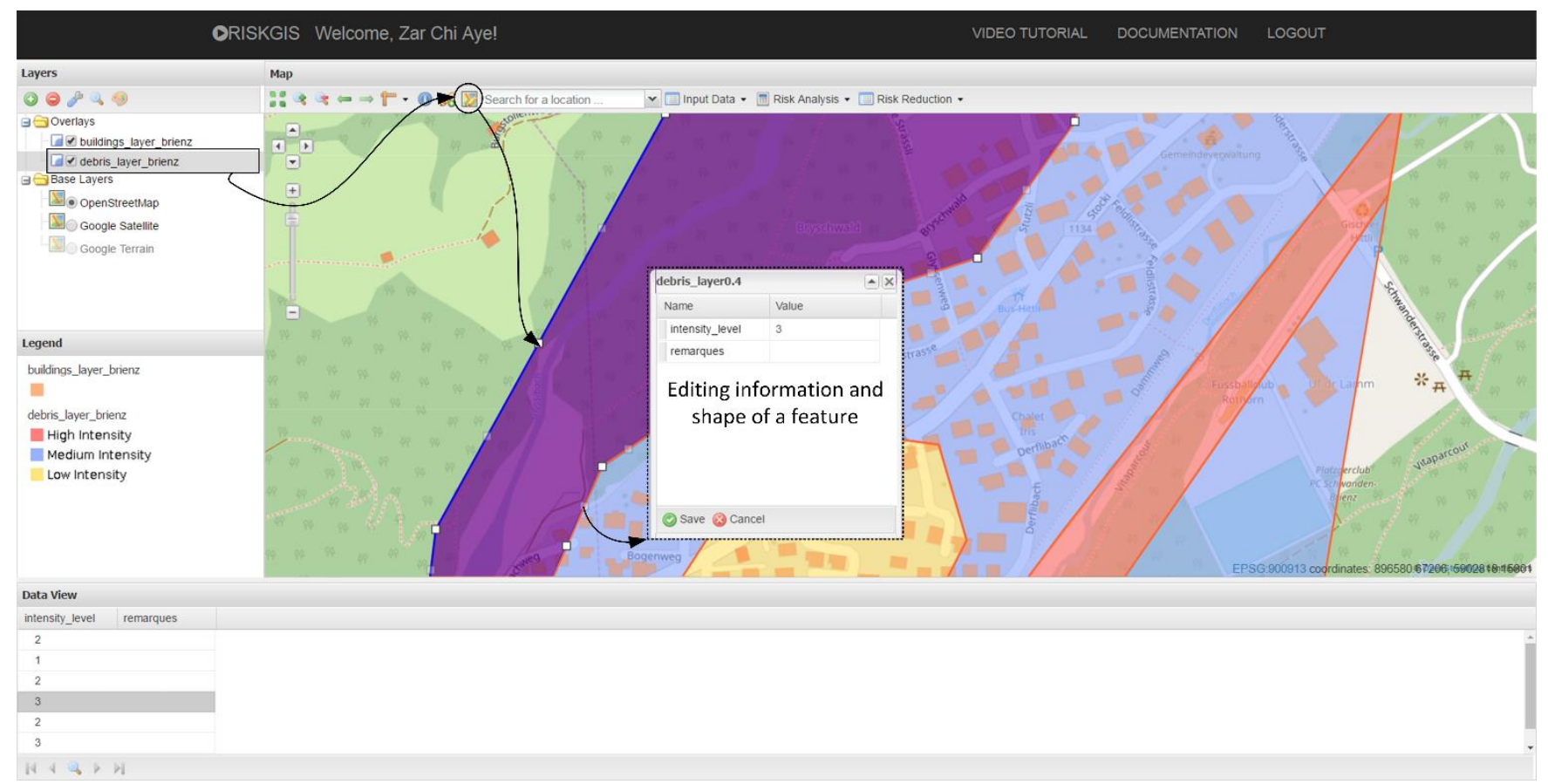

Figure 9: Illustration of the popup interface of the "Editing existing feature" tool for modification of a layer's feature (for example, in editing the hazard intensity map) in the RISKGIS platform. 
Nat. Hazards Earth Syst. Sci. Discuss., doi:10.5194/nhess-2017-85, 2017

Manuscript under review for journal Nat. Hazards Earth Syst. Sci.

Discussion started: 1 March 2017

(c) Author(s) 2017. CC-BY 3.0 License.

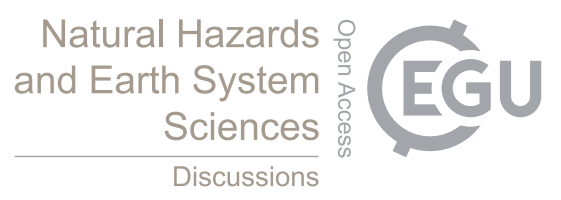

\subsubsection{Results and discussion}

In the exercise feedback questionnaire, we asked students: 1) to explain what they have learnt from doing this exercise (in few words); 2) to respond to five questions on a simple Likert scale of 1 to 5 (Strongly disagree to Strongly agree) for the feedback on the exercise; and 3) to mention aspects of the exercise to be improved and if there are any supplementary suggestions/comments. Fig. 10 shows the average ratings of the five following questions (Q1-Q5) asked:

Q1. This exercise is interesting.

Q2. This exercise is useful for my learning and understanding.

Q3. This exercise is helpful in understanding of how real situation works.

Q4. This exercise stimulates my interests in risk management.

Q5. I want to do practical exercises with such interactive tools.

Out of the obtained 55 responses, $70 \%$ of students agreed that the exercise was interesting and useful for their learning and understanding. About $60 \%$ of students mentioned that this exercise helped in understanding of how the reality works, while $55 \%$ and $53 \%$ of students indicated that this exercise stimulated their interests in risk management and that they want to do practical exercises using this kind of interactive tools. To sum up their feedback on what they have learnt in this exercise,

15 students mentioned that this exercise allowed them to familiarise concretely with risk management by engaging them in the elaboration of a solution for a real case, in which they have learnt to identify potential risks of a given area, develop an effective and realistic alternative, and finally to estimate the profitability of their solution. They also stated that they learned to consider different possible alternatives which are financially and physically adequate to reduce risk, as well as advantages and disadvantages of measures taken (such as financial and ecological aspects), while providing a better understanding of the

20 notions of risk calculation and cost-benefit analysis for the exam. Besides, students indicated that they realized the complexity of risk systems in practical cases (such as difficulty in quantifying the impact of a natural disaster and finding a perfect alternative), and that they have seen a direct application of the course, making them possible to put into practice and understand theories seen in course during the semester in a very concrete way, thanks to the automation of the entire computational part, which is not always easy to assimilate theories without concreate case studies. 
Nat. Hazards Earth Syst. Sci. Discuss., doi:10.5194/nhess-2017-85, 2017

Manuscript under review for journal Nat. Hazards Earth Syst. Sci.

Discussion started: 1 March 2017

(c) Author(s) 2017. CC-BY 3.0 License.
Natural Hazards

and Earth System

Sciences

Discussions

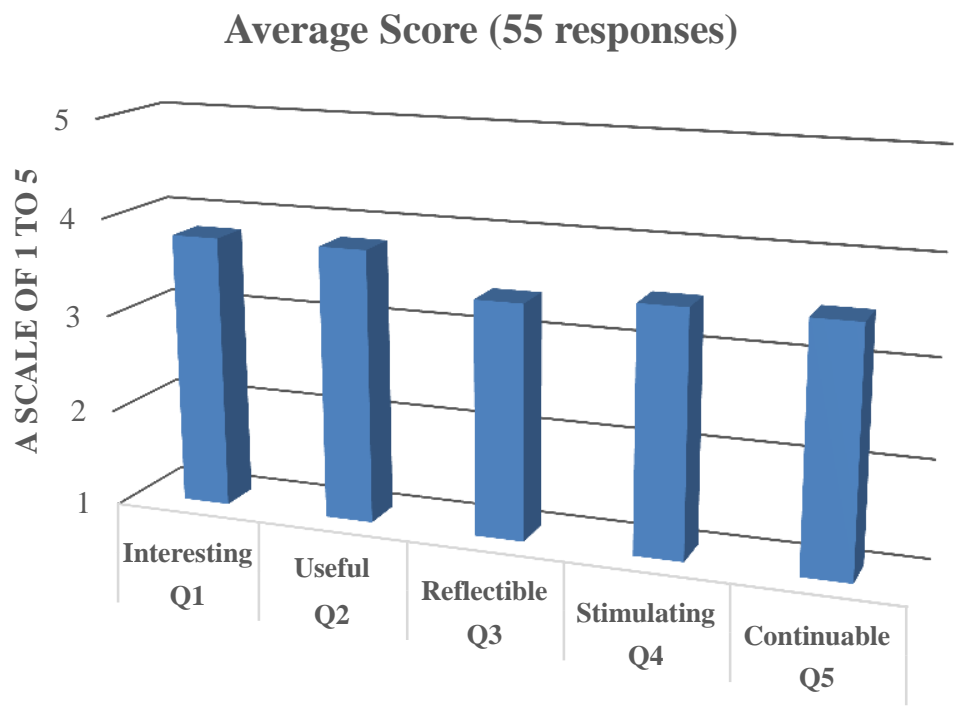

Figure 10: Exercise feedback on a 5-point Likert scale (Strongly disagree to strongly agree).

Regarding aspects of the exercise to be improved, students mentioned mainly to provide them with additional sources and reference values for a better cost estimation of measures (for example, price per cubic meter of a dike). They also highlighted that it would have been useful to present more concretely on how various measures reduce the hazard or risk of a given area (for example, effectiveness of a dike in comparison with a concrete dam or the maintenance of a forest in an area prone to debris flows). In addition, students suggested to make smaller groups (no more than 3) and distribute the exercise on several sessions (for example, 4 x 1 hour) with a possibility to select a case study among a predefined list with different subjects and countries so that they can learn more about measures and their effectiveness in different cases. Besides, they have also stated that the use of the RISKGIS platform should be presented during the course (than the video tutorial) to better understand how to use it and interpret the results. For additional comments, students mentioned it was a very good idea to use an application like this as it allowed to integrate theories in practice, and that it would be more interesting to do more exercises in this genre and less exercises on the paper. While they appreciated for being "put into real situation", they indicated that more data and information should be provided to estimate important parameters for calculating risk or costs, in particular cost of measures and their effectiveness, which was the main issue they encountered in this exercise. It would have been helpful to mention, during the course, a list of the various protective measures with some information (advantages, disadvantages, typical use, costs, lifetime, etc.).

Regarding the user evaluation feedback, we used the same SUS questionnaire (Q1-Q10 as in Sect. 4.1.3 of the first scenario) to evaluate the performance of the platform. For a total of 52 responses, we achieved an average SUS score of 58.03/100 and the overall satisfaction of the platform was 6.12/10, which is lower than the results of the first scenario. This is mainly because of several issues we discussed above in the exercise feedback (as pointed out by students). To summarize students' 
Nat. Hazards Earth Syst. Sci. Discuss., doi:10.5194/nhess-2017-85, 2017

Manuscript under review for journal Nat. Hazards Earth Syst. Sci.

Discussion started: 1 March 2017

(c) Author(s) 2017. CC-BY 3.0 License.
Natural Hazards

and Earth System

Sciences

Discussions

(c) (i)

feedback on different sections, students mentioned that the main objective of the platform is the apprehension and management of environmental risks in the context of natural hazards, and thanks to it, several hypotheses can be formulated to find interesting solutions. Though it is very easy to use, they need prior knowledge to obtain plausible results, and that it would be interesting to make this tool accessible to users unfamiliar with geo-social concepts of risk, in particular by integrating a workflow or a section explaining different functions that RISKGIS can implement. For the technical aspects, students suggested that it would be good to be able to style measures (for example, dike in blue and tunnel in black) for visual appearance and to create shapes other than polygons in designing measures. It was also mentioned that the interface could be more intuitive with addition of keyboard shortcuts, better presentation of system messages, grouping of overlay layers and ability to save the entire work as a project with layers added so that it would not necessary to add layers again

10 one-by-one into the map. In addition to these technical aspects, many suggested that estimated cost of measures should be proposed automatically, and that the reduction of areas at risk should be guided (or simulated based on proposed measures). Since it was difficult for them to have an idea of the costs and the effectiveness of the measures envisaged, it would be nice to add a database with this type of information. Some students commented additionally that it is a good idea of the real work done with a lot of potential, and that they will also appreciate for having a user guide to test it in a setting other than the course, which would allow them to know how to create a layer or import data.

\subsection{Scenario 3: Learning the role of different actors in risk management using RISKGIS}

The aim of this scenario is to better understand the complexity and conflicting interests of involved actors in the decision making process of risk management through role-playing of different actors such as technicians, authorities and decision makers. This exercise was carried out with 13 Master students of the advanced quantitative risk and vulnerability course on

2014 November 2016, using the RISKGIS platform and a real case study in Brienz, Switzerland. The structure of the exercise is based on the complete learning framework (see Fig. 2), and it was performed individually and in groups (3-4 students per group), depending on different stages of the exercise (Fig. 11). For the individual part of the exercise, students can register themselves through the platform to do the exercise individually, while group logins are given to each group of students for the other parts of the exercise in groups. As in previous scenarios, by following the given tutorial exercise, role description

25 sheet and data of the study area, students analyse risk, propose risk reduction measures, perform cost-benefit and multicriteria analyses to have an overview of risk management framework with involvement of different actors. At the end of the exercise, students are asked to submit an exercise and a user evaluation feedback to evaluate the performance of the exercise and platform, as well as group functioning questionnaires for the group decision making part of the exercise. The results of feedback and group functioning questionnaires are presented and discussed in Sect. 4.3.2. 
Nat. Hazards Earth Syst. Sci. Discuss., doi:10.5194/nhess-2017-85, 2017

Manuscript under review for journal Nat. Hazards Earth Syst. Sci.

Discussion started: 1 March 2017

(c) Author(s) 2017. CC-BY 3.0 License.

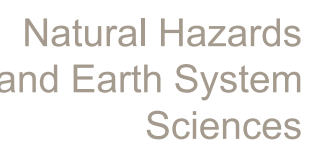

Discussions

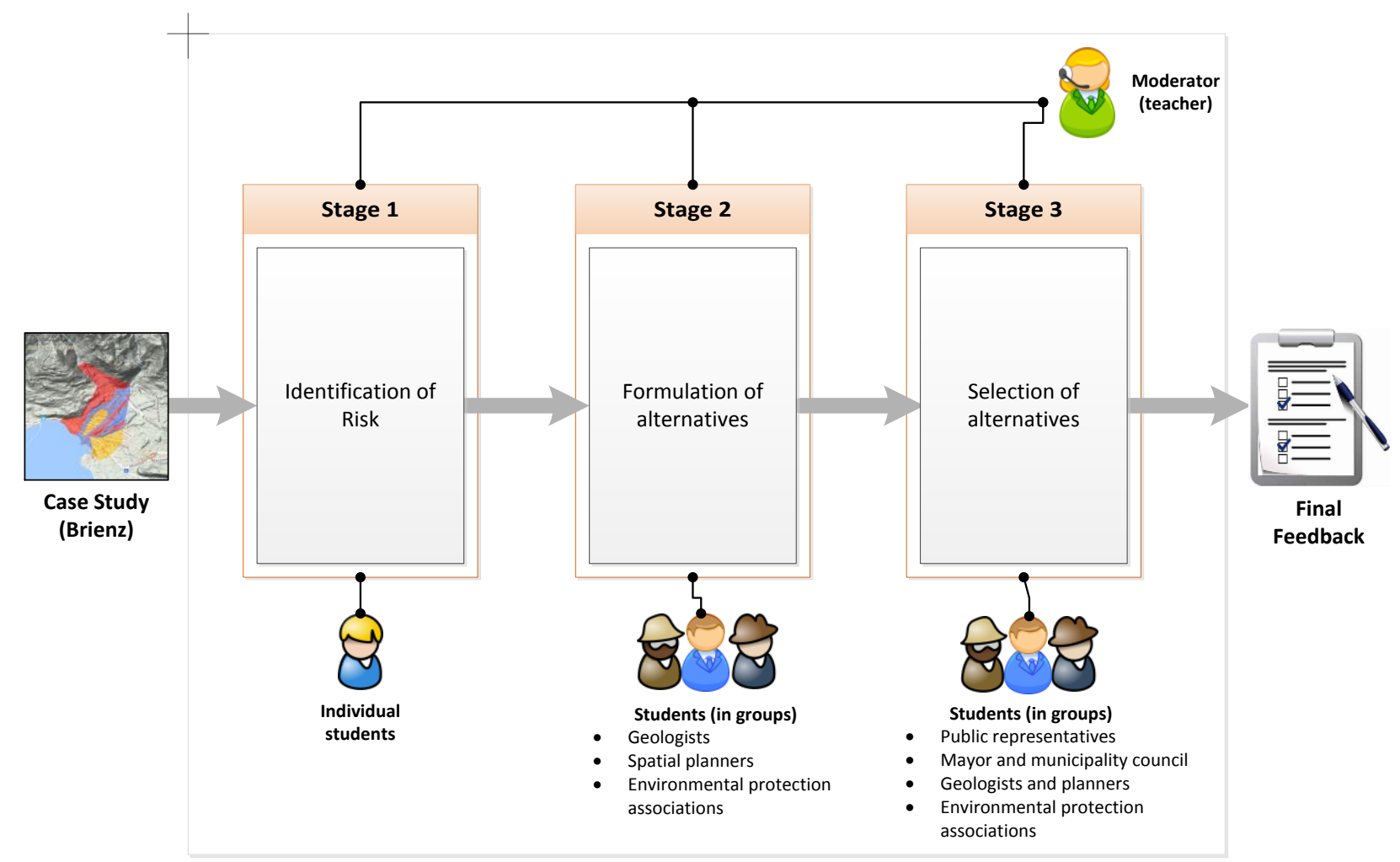

Figure 11: Workflow (structure) of the scenario illustrating the different stages of the exercise with involvement of different groups (Source: modified from Aye et al., 2016c). The same case study Brienz (Switzerland) of the second scenario (Sect. 4.2.1) is used.

\section{4.3.1 Stages of the scenario}

The same study area and input data of the previous scenario 2 is used (i.e. buildings and debris flow hazard map of Brienz, Switzerland) in this exercise (see Sect. 4.2.1). This exercise includes stages of the previous scenario 2 (Sect. 4.2.2), however, with an additional component of MCA for the group decision making part of the exercise. In the first stage, each student calculates risk individually using default parameters. During the second stage, the class is divided into three groups: geologists, spatial planners and environmental associations. Depending on their played roles and outcomes of the calculated risk in the first stage, each group is asked to: 1) propose an alternative; 2) estimate costs of the alternative; 3) re-calculate risk after the consideration of alternative; and 4) calculate cost-benefit ratio of that proposed alternative. Then in the third stage of the exercise, alternatives proposed by different groups are evaluated and ranked with all involved actors using the Compromise Programming method implemented in the RISKGIS platform. The decision criteria are pre-defined by the moderator (i.e. teacher) beforehand to evaluate the performance of alternatives (which were proposed by each group from the previous second stage). Through the interactive discussion with all groups of students in the classroom, we evaluate and assign performance values of alternatives for each criterion, for example, the cost of the alternative proposed by a certain group of actors is very high. These performance values can be either qualitative or quantitative depending on the type of 
Nat. Hazards Earth Syst. Sci. Discuss., doi:10.5194/nhess-2017-85, 2017

Manuscript under review for journal Nat. Hazards Earth Syst. Sci.

Discussion started: 1 March 2017

(C) Author(s) 2017. CC-BY 3.0 License.
Natural Hazards

and Earth System

Sciences

Discussions

(c) $\underset{\mathrm{BY}}{(\mathrm{P})}$

criteria. For the qualitative criteria, they vary ranging from 1 (Extremely Low) to 9 (Perfect). For this third stage of the exercise, we divided the class into four groups of actors (i.e. public representatives, mayor and municipal council, geologists and planners, and environmental associations). After that, each group ranks alternatives by assigning weights to criteria (Fig. 12). In other words, depending on their played roles, each group decides and classifies the importance of the criteria (with a

5 scale of 1: the least important to 5: the most important criteria). These weights are normalized (i.e. weight values are divided by the total) for ranking of alternatives. The ranking of alternatives for each group is then calculated dynamically with the given weight set and evaluation matrix using Eq. (6) and (7). Finally, all groups come together and negotiate to achieve a final weight set for the final decision through a classroom discussion moderated by the student group, who plays the role of mayor and municipal council.

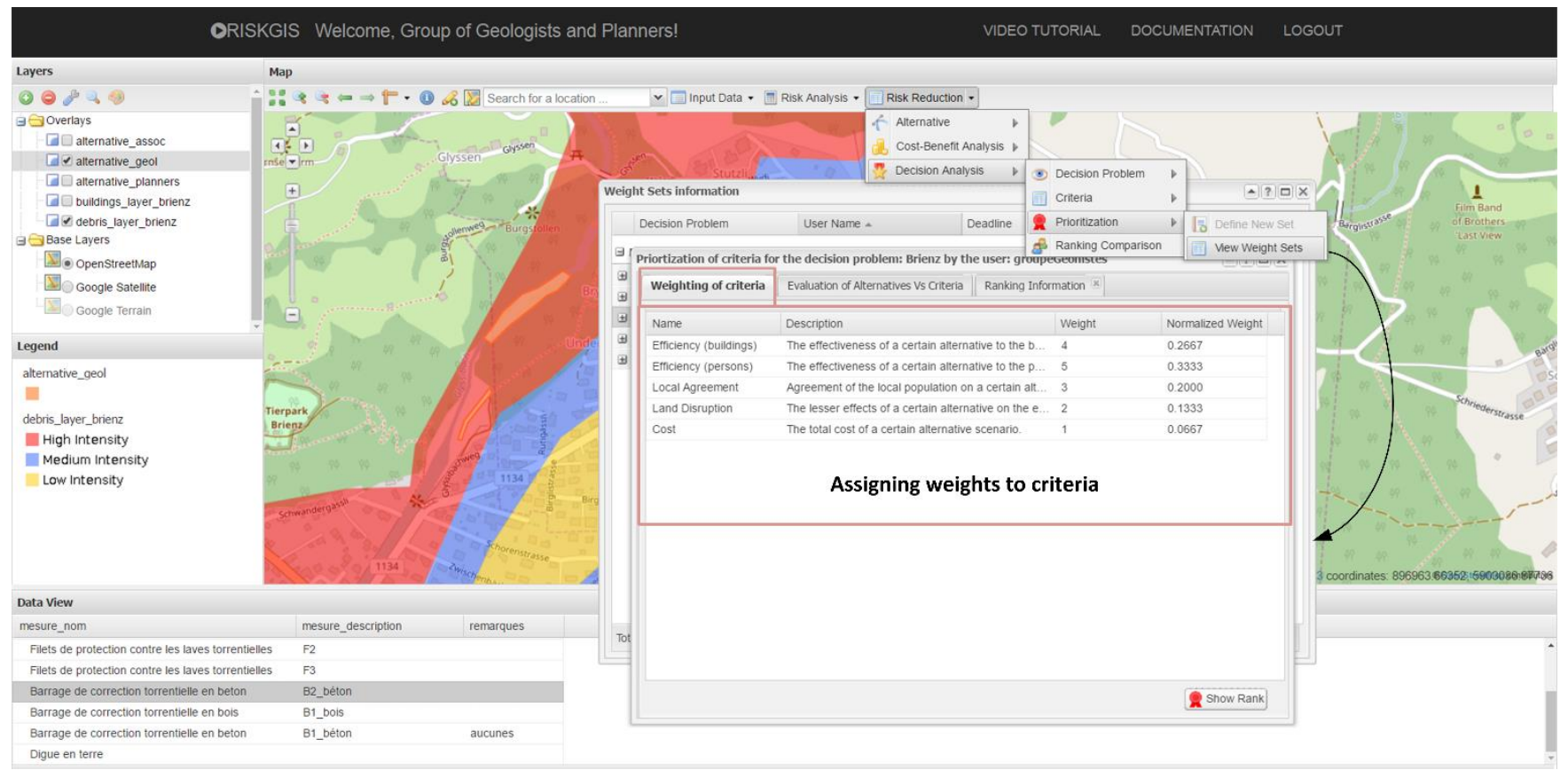

Figure 12: Illustration of the window panel for assigning weights to criteria (i.e. in the first tab) by a group of actors (with a scale of 1: the least important to 5: the most important criteria) in the RISKGIS platform, which is accessible through "Risk Reduction $\rightarrow$ Decision Alaysis $\rightarrow$ Prioritization" menu. The evaluation matrix (Alternatives Vs Criteria) is located in the second tab, and results (ranking of alternatives) can be visualized in the third tab based on assigned weights.

\section{$15 \quad$ 4.3.2 Results and discussion}

In this exercise, two types of feedback were collected: 1) exercise and user evaluation feedback for evaluation aspects related to student exercise and user experience of the learning platform, and 2) group functioning feedback for understanding of aspects related to group functioning and group decision making. 
Nat. Hazards Earth Syst. Sci. Discuss., doi:10.5194/nhess-2017-85, 2017

Manuscript under review for journal Nat. Hazards Earth Syst. Sci.

Discussion started: 1 March 2017

(c) Author(s) 2017. CC-BY 3.0 License.
Natural Hazards

and Earth System

Sciences

Discussions

(c) $\underset{\mathrm{BY}}{(i)}$

\section{Evaluation feedback}

For the exercise feedback, we used the same feedback form of the scenario 2 (see Questions 1-5 of the exercise feedback in Sect. 4.2.3). Out of the 13 responses of students (Fig. 13), the best scores were achieved for Q1 and Q3. About $92 \%$ and $85 \%$ of students agreed that the exercise was interesting and helpful in understanding of the real world situation. While $62 \%$ of

5 students found the exercise useful for their learning and understanding, as well as stimulating their interests in risk management. Finally, 54\% of students indicated that they want to do practical exercises with this kind of interactive tools. Regarding what they learned from doing this exercise, it was mentioned that physical issues play only a tiny part while financial aspect plays a very important role with a lot of points to be taken into account, and that a decision process is long and demands for negotiations. It was also stated that they have learnt in reflecting which risk protection measures to take,

10 and to have a general vision with the viewpoints of many involved actors. For the aspects to be improved, students expressed again to have more information on the costs of measures and utilization of the platform.

\section{Average Score (13 responses)}

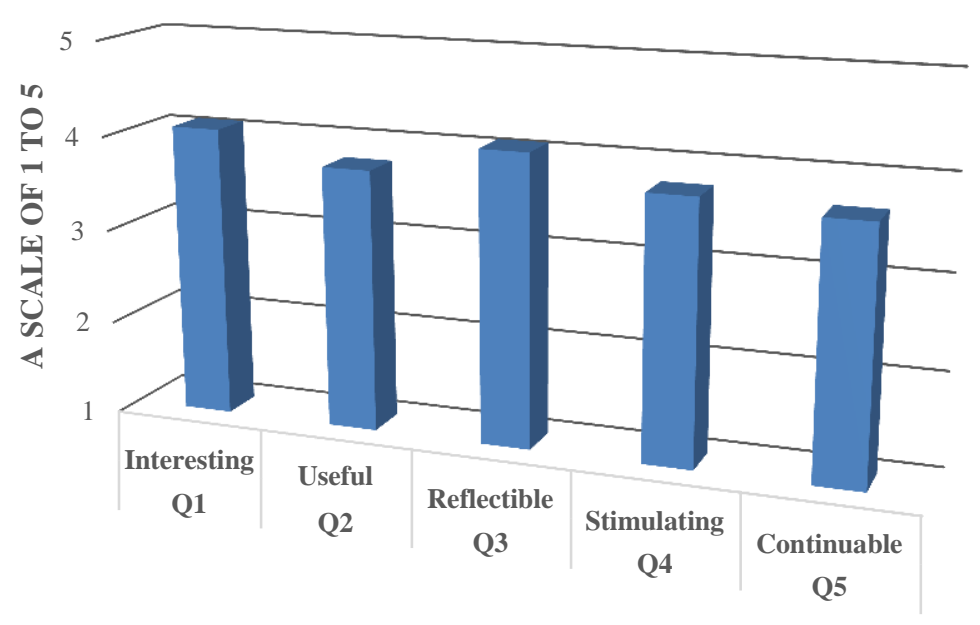

Figure 13: Exercise feedback on a 5-point Likert scale (Strongly disagree to strongly agree).

15 Regarding the user evaluation feedback (see Sect. 4.2.3 for the questions Q1-Q10), we achieved an average SUS score of $64.62 / 100$ and the overall satisfaction of the platform was 6.77/10 for 13 students, which is lower than the results of the first scenario but a bit higher than the second scenario. Nevertheless, good scores were achieved for Q7 (i.e. they imagine that most people would learn to use this system very quickly) and Q8 (i.e. they do not found the system very cumbersome to use). Concerning the purpose of the platform, students mentioned that it is to understand different stages and roles of actors upon creation of a risk reduction project in an area. It was also mentioned that the platform is to perform a quick and simple qualitative analysis of risk with some pseudo-quantitative data, cost and cost-benefit calculation with the ability to compare several alternatives and opinions. Regarding aspects of the platform to be improved, it was stated that certain technical 
Nat. Hazards Earth Syst. Sci. Discuss., doi:10.5194/nhess-2017-85, 2017

Manuscript under review for journal Nat. Hazards Earth Syst. Sci.

Discussion started: 1 March 2017

(c) Author(s) 2017. CC-BY 3.0 License.
Natural Hazards

and Earth System

Sciences

Discussions

(c) $\underset{\mathrm{BY}}{(i)}$

aspects can be improved (especially in editing features and displaying layers), and that it could be great to add some basic impacts of protection structures (i.e. their costs and effectiveness - how to modify/reduce hazard zones).

\section{Group functioning feedback}

5 In this scenario, two group functioning questionnaires (based on a scale of 1 to 5: Not at all to absolutely) are also collected to understand how a group with same and mixed roles of actors functions. The following Fig. 14 shows average scores of the questions (Q1-Q5) asked in this first questionnaire with same roles, i.e. for the first round of selection of alternatives (in stage 3 of the exercise) with groups of same actors. The questions are as follows:

Q1. Does your group struggle with the problem of setting goal (i.e. figuring out the desired outcome)?

Q2. Do the people in your group all agree upon a common goal?

Q3. a) Were there conflicts in your group in prioritizing decision criteria?

b) If there were conflicts, what is the level of severity?

Q4. Do you agree with assigned weights (of your group) on decision criteria?

Q5. Overall, are you satisfied with functioning of your group?

\section{Average Score (13 respones)}

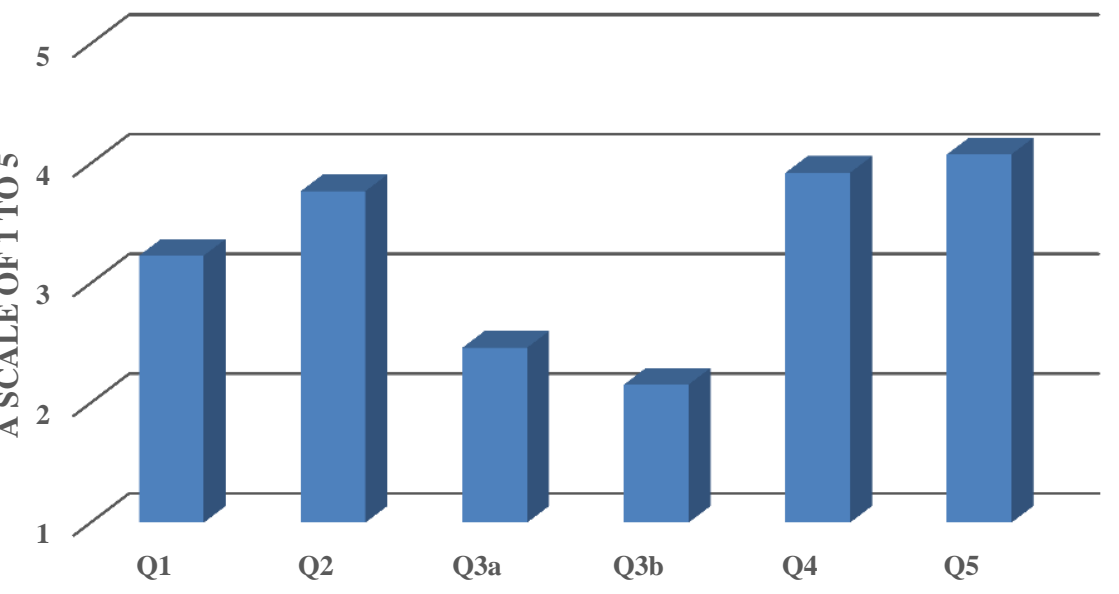

Figure 14: Group functioning feedback (same roles) based on a 5-point Likert scale (Not at all to absolutely).

Out of the obtained responses, at a moderate-to-high level (scale of 3-to-5), 83\% of students mentioned that they had struggles in figuring out the desired outcome. However, about $92 \%$ of students indicated that they have come to an agreement upon a common goal. Even though 58\% of students had conflicts in prioritizing decision criteria within their groups (with a moderate severity of 38\% and a high severity of $0 \%$ ), $92 \%$ of students agreed with assigned weights of their groups on decision criteria, and none of the students were not satisfied with functioning of their groups. In this questionnaire, we also asked students to explain their impressions in doing this exercise with their groups, and students commented that it 
Nat. Hazards Earth Syst. Sci. Discuss., doi:10.5194/nhess-2017-85, 2017

Manuscript under review for journal Nat. Hazards Earth Syst. Sci.

Discussion started: 1 March 2017

(c) Author(s) 2017. CC-BY 3.0 License.
Natural Hazards o

and Earth System

Sciences

Discussions

(c) (i)

was an interesting exercise simulating a real case for students by taking a certain view point of actors in risk management and they had to consider other aspects which they do not necessarily consider. Regarding their opinions of whether group work helps tackling problem at hand, most students gave positive feedback mentioning that the group work can help them to see the aspects which they probably would not see alone and that there has an advantage of thinking in certain aspects because of different opinions. While it was also mentioned that it is difficult to set goals for management as it takes a lot of aspects to consider as well as viewpoints of different groups of actors.

For the second questionnaire with mixed roles of actors, Fig. 15 shows average scores (in groups) of the questions (Q1-Q5) asked for the final round of selection of alternatives (in stage 3 of the exercise) with groups of mixed actors. The questions

10 are as follows:

Q1. What is your level of influence in your group?

Q2. Do you agree with the final decision taken?

Q3. Were your opinions/suggestions taken into account?

Q4. Did you feel participated in the decision-making process?

15

\section{Average Score (4 groups/13 responses)}

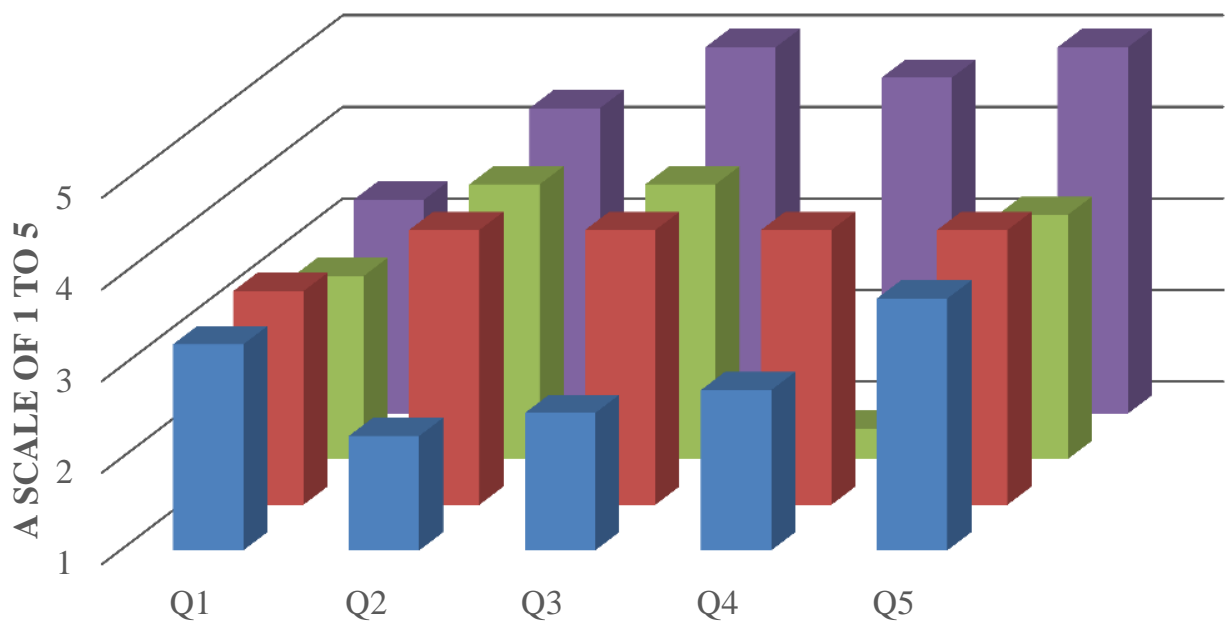

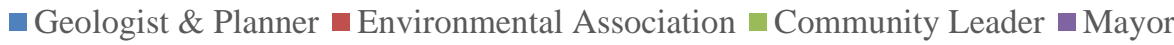

Figure 15: Group functioning feedback (mixed roles) based on a 5-point Likert scale (Not at all to absolutely).

As can be seen in Fig. 15, the group of community leaders had the lowest level of influence compared to the rest of the groups. Except the technician group of geologists and planners, all groups agreed with the final decision taken (by the mayor with discussion in the classroom). The similar result was achieved for the question of whether their opinions were taken into 
Nat. Hazards Earth Syst. Sci. Discuss., doi:10.5194/nhess-2017-85, 2017

Manuscript under review for journal Nat. Hazards Earth Syst. Sci.

Discussion started: 1 March 2017

(c) Author(s) 2017. CC-BY 3.0 License.

account, in which the technician group obtained the lowest score of 2.5. Regarding the participation question, the group of community leaders mentioned that they did not feel participated in the process (i.e. a score of 1.33), following by the technician group with a score of 2.75. Overall, for this final round of selection process, an average score of 4.08 was achieved for the satisfaction with group functioning. In general, amongst other groups, we can see that mayor achieved the

5 highest scores, followed by the group of environmental association. This result shows the consistency between collected feedback and exercise, since the final decision taken by the mayor is the solution proposed by the group of environmental association. To sum up the additional questions we asked in this questionnaire, students mentioned that mayor took the final decision by discussing with all groups, and for mayor, cost was the better choice despite the limitation of risk for human beings. It was also stated that group decision making could be improved by having more information of the considered

10 problem, dealing more with all aspects (which they could not due to time limitations) and defining the common goal amongst involved actors (i.e. for example, saving the lives).

\section{Discussion and conclusion}

In this paper, we presented an open-source web-GIS based platform (RISKGIS) for learning risk management of geohazards. Based on previous related research works of authors (Aye et al., 2016c; Olyazadeh et al., 2016), this platform was adapted to

15 methods and approaches applied in Switzerland for undergraduate and postgraduate students learning in environmental risk, and advanced risk and vulnerability courses at the University of Lausanne. It replaces some exercises of the courses, in particular for studies on large areas which cannot be easily calculated by hand, for the rapid evaluation of risk before and after the consideration of protection measures and to test the efficiency of measures using a simple cost-benefit analysis tool. Furthermore, it integrates a multi-criteria evaluation tool for selection of measures collaboratively in the context of group

20 decision making. This research work was carried out under the framework of the Innovative Teaching project, and aimed at enhancing teaching concepts of risk management through real case studies and the practical application of an innovative web-GIS based platform, without needing to deal with commercial software licences and synthetic case studies for exercises. In this research, taking the advantage of new (collaborative) web-GIS capabilities, students can define endangered zones spatially and calculate cost of a disaster under different scenarios considering protective measures in groups. The classical GIS systems do not allow such collaborative activities, which is indispensable to risk management of natural hazards, between students through exchanges of risk management proposals or between students and the teaching team. Besides, learning of students can be evaluated and monitored via the web-GIS platform.

Three scenarios (exercises) were developed and applied for student learning using the RISKGIS platform with real case 30 studies. For the first exercise, a rapid risk calculation tool of the platform was introduced to Bachelor students of the environmental risk course, and favourable responses were achieved from students mentioning their interests in performing more in-depth exercises using the platform. Students also agreed that most would learn to use this platform very quickly and 
Nat. Hazards Earth Syst. Sci. Discuss., doi:10.5194/nhess-2017-85, 2017

Manuscript under review for journal Nat. Hazards Earth Syst. Sci.

Discussion started: 1 March 2017

(c) Author(s) 2017. CC-BY 3.0 License.

it was not very cumbersome to use, while the support of a technical person might be needed for some, since students were not given training or use of the platform before doing the actual exercise (except only a short presentation of the exercise and platform). Afterwards, a much longer second exercise was carried out with same students (in groups) starting from the risk calculation to the selection of protective measures, in which students are required to submit a group report with justifications

5 of their choices and results. Overall, feedback analysis of this exercise showed that $70 \%$ of students found the exercise interesting and useful, while about $53 \%$ to $60 \%$ of students mentioned that it reflected the real situation, stimulating their interests in risk management and doing exercises with such interactive tools. The main issue students encountered in this exercise was the lack of information on costs of protective measures, their effectiveness and modification of hazard zones, as students are still in a learning phase and have limited knowledge unlike experts. This aspect could be significantly improved

10 by providing a more complete data with additional materials and information during or before the exercises. Besides, as one student interestingly suggested, this exercise could be carried out in parallel with the course since the beginning of the semester until the end, so that it would be very interesting and would greatly stimulate students' interests in risk management more, since the theory is not always obvious to assimilate despite a series of exercises during the semester. Finally, the last exercise was performed with master students from advanced quantitative risk and vulnerability course, by following the same structure of the second exercise with additional component on collaborative group decision making using multi-criteria analysis. In this exercise, students (in groups) play roles of different actors in formulation and selection of risk management alternatives. Feedback responses indicated that most students found this exercise interesting and helpful in understanding of the real world situation, while other aspects could be further improved such as information on costs of measures and utilization of the platform. It was also observed that students were satisfied with functioning of their groups (same roles)

20 despite there were some conflicts in in prioritizing decision criteria and setting upon a common goal in the beginning. However, when different groups come together for final decision, highest satisfaction scores in group functioning were achieved for the mayor's group (i.e. the final decision maker) followed by the group of environmental protection associations (i.e. the winning group out of all proposed alternatives). This was the same for the level of participation in group decision making, and technical group (i.e. geologists and planners) mentioned their disagreement with final decision taken. It was indeed interesting to see how the situation reflects conflicting interests of different actors through the role-playing exercise and interactive discussion in the classroom.

To conclude, feedback obtained from students could be used to further improve the platform and presentation of the exercises, which would increase students' interests, applicability and usability of the presented learning platform. Although

30 there are some aspects to be improved from technical and learning perspectives, students mentioned that these exercises stimulate reflection and creativity by putting them in the position of decision makers facing a disaster. That made them realized that decisions can be complicated and complex not only at the level of what is to be done but also at the level of budget and how one will do to minimize the risk in question. Importantly, it made them possible to have connections with what they learned during the course, permitting also to better analyse and visualize areas at risk for in-depth risk 
Nat. Hazards Earth Syst. Sci. Discuss., doi:10.5194/nhess-2017-85, 2017

Manuscript under review for journal Nat. Hazards Earth Syst. Sci.

Discussion started: 1 March 2017

(c) Author(s) 2017. CC-BY 3.0 License.

management linked to a real event. From the teaching perspective, this research work brings several benefits to both students and teachers in terms of feedback by allowing: 1) to confront and discuss risk reduction solutions proposed by students, 2) to compare them with real cases, and 3) to simulate and evaluate the importance of different actors in decision making. This approach attempts to encourage exchange between students or between teachers and students through personal schoolwork

5 and such a collaborative approach is the basic of any modern risk management involving consultation and participative approaches. Moreover, this makes possible to support in-depth learning through the involvement of students in different activities, encouraging their motivation through active involvement and different moments of discussion. Notably, it also creates connections between theory and practice, allowing students to better understand what they have learnt during the course lectures. Last but not least, group activities underpin the development of collaborative skills and decision making

10 which they can later transfer to similar future situations. Regarding the collected feedback of students, some of the improvements are being considered and next exercises using the RISKGIS platform are planned in this spring semester 2017 for Bachelor students of the environmental risk course.

\section{Author contribution}

All authors have contributed either conceptually or physically to design and materialize this research work, project and

15 article. Zar Chi Aye developed the RISKGIS platform, carried out overall exercises, analysed feedback of students and wrote the manuscript with the kind support and guidance of remaining authors. Roya Olyazadeh assisted in preparing data, tutorial exercises, video demos, SUS and feedback questionnaires via Moodle. Particularly, Roya Olyazadeh designed the quiz test and the first exercise along with tutorial video, based on her previous research work. Selection of study areas, preparation of hazard maps and exercises with students are supported and guided by Michel Jaboyedoff and Marc-Henri Derron. Johann

20 Lüthi (Pedagogical engineer of the Faculty of Geosciences and Environment) provided suggestions and feedback throughout the project period as well as assistance in particular to aspects related to the Moodle platform.

\section{Acknowledgements}

The authors would like to thank all participated students of the Environmental Risk and Advanced Quantitative Risk and Vulnerability courses (spring and autumn semesters, 2016) of the University of Lausanne, who performed their exercises using RISKGIS, for giving their valuable feedback and suggestions on the exercises and platform. We would also like to express our thanks to the participated assistants of our Risk Analysis group for translating tutorial exercises into French and assisting students during the exercise sessions of the courses. We acknowledge the funding provided by Fonds d'innovation pédagogique (FIP, 2016) of the University of Lausanne (http://www.unil.ch/fip/), which made possible to carry out this exciting research work for active learning with students in risk management, as well as the support of Deborah Dominguez 
Nat. Hazards Earth Syst. Sci. Discuss., doi:10.5194/nhess-2017-85, 2017

Manuscript under review for journal Nat. Hazards Earth Syst. Sci.

Discussion started: 1 March 2017

(c) Author(s) 2017. CC-BY 3.0 License.

(c) (i)

(Pedagogical counsellor of CSE, Centre de Soutien à l'Enseignement). Last but not least, we also thank to our former colleague, Pierrick Nicolet, for his kind support and contribution in the proposal submission of this research project.

\section{References}

Audet, R. H. and Paris, J.: GIS implementation model for schools: Assessing the critical concerns, Journal of Geography, 96, $5 \quad 384-300,1997$.

Aye, Z.C., Jaboyedoff, M., Derron, M. H., van Westen, C. J., Hussin, H. Y., Ciurean, R. L., Frigerio, S., and Pasuto, A.: An interactive web-GIS tool for risk analysis: a case study in the Fella River Basin, Italy, Nat. Hazards Earth Syst. Sci., 85-101, 2016a.

Aye, Z.C., Sprague, T., Cortes, V.J., Prenger-Berninghoff, K., Jaboyedoff, M., and Derron, M.-H.: A collaborative (web-

10 GIS) framework based on empirical data collected from three case studies in Europe for risk management of hydrometeorological hazards, International Journal of Disaster Risk Reduction, 15, 10-23, doi: 10.1016/j.ijdrr.2015.12.001, $2016 \mathrm{~b}$.

Aye, Z.C., Charrière, M., Olyazadeh, R., Derron, M.-H., and Jaboyedoff, M.: Evaluation of an open-source collaborative webGIS prototype in risk management with students, Journal of Spatial Information Research, 24 (3), 169-179, doi: 10.1007/s41324-016-0018-x, 2016c.

15 Barstow, D.: Geographical information system: new tools for student exploration, Hands On, 17, 10-13, 1994.

Bodzin, A. M. and Anastasio, D.: Using web-based GIS for earth and environmental systems education, Journal of Geoscience Education, 54 (3), 295-300, 2006.

Bonwell, C. C. and Eison, J.: Active Learning: Creating Excitement in the Classroom, ASHE ERIC Higher Education Report No. 1, George Washington University, Washington DC, USA, 1991.

20 Brandl, K.: Are you ready to "Moodle"?, Language Learning \& Technology, 9, 16-23, 2005.

Bründl, M., Krummenacher, B., Rheinberger, C., and Winkler, C.: Formeln zur Berechnung des Risikos bei Naturgefahren, Version 21, December 2011.

Brooke, J.: SUS-A quick and dirty usability scale, Usability evaluation in industry, 189 (194), 4-7, 1996.

Bründl, M., Romang, H.E., Bischof, N., and Rheinberger, C.M.: The risk concept and its application in natural hazard risk 25 management in Switzerland, Natural Hazards and Earth System Sciences, 9(3), 801-813, 2009.

Careaga, M. D. P. R.: WebGIS applied to improve spatial knowledge of high school students, Master thesis dissertation, Universidade Nova de Lisboa, available at: http://hdl.handle.net/10362/14566 (last access: 31 January 2017), 2014.

Carrarra, A. and Guzzetti, F. (Eds): Geographical Information Systems in Assessing Natural Hazards, Kluwer Academic Publishers, Boston, 360 pp., 1995.

30 Carver, S., Evans, A., and Kingston, R.: Developing and Testing an Online Tool for Teaching GIS Concepts Applied to Spatial Decision-making, Journal of Geography in Higher Education, 28(3), 425-438, doi: 10.1080/0309826042000286983, 2004. 
Nat. Hazards Earth Syst. Sci. Discuss., doi:10.5194/nhess-2017-85, 2017

Manuscript under review for journal Nat. Hazards Earth Syst. Sci.

Discussion started: 1 March 2017

(C) Author(s) 2017. CC-BY 3.0 License.
Natural Hazards

and Earth System

Sciences

Discussions

(c) $\underset{\mathrm{Br}}{\mathrm{B}}$

Coppock, J. T.: GIS and natural hazards: an overview from a GIS perspective, in: Geographical Information Systems in Assessing Natural Hazards, edited by: Carrara, A. and Guzzetti, F., Volume 5 of the series Advances in Natural and Technological Hazards Research, 21-34, 1995.

Crozier, M. J. and Glade, T.: Landslide hazard and risk: issues, concepts and approach, in: Landslide hazard and risk, edited

5 by: Glade, T., Anderson, M., and Crozier, M. J., John Wiley \& Sons Lt, Chichester, UK, 1-40, 2005.

De Marchi, B. and Scolobig, A.: The views of experts and residents on social vulnerability to flash floods in an Alpine region of Italy, Disasters, 36(2), 316-337, 2012.

Dragićević, S.: The potential of web-based GIS, Journal of Geographical Systems, 6(2), 79-81, 2004.

Dragićević, S. and Balram, S.: A Web GIS collaborative framework to structure and manage distributed planning processes,

10 Journal of Geographical Systems, 6(2), 133-153, 2004.

EBIBALPIN, Alpine Geo-Bibliography, University of Lausanne, available at: http://ebibalpin.unil.ch/, last access: 16 March 2015.

EconoMe: Wirksamkeit und Wirtschaftlichkeit von Schutzmassnahmen gegen Naturgefahren: Formelsammlung, 2015.

Fell, R. and Hartford, D.: Landslide risk management, in: Landslide Risk Assessment, edited by: Cruden, D. and Fell, R.,

15 Balkema, Rotterdam, 51-109, 1997.

Fell, R., Ho, K. K. S., Lacasse, S., and Leroi, E.: A framework for landslide risk assessment and management, in: Landslide

Risk Management, edited by: Hungr, O., Fell, R., Couture, R., and Eberhardt, E., Taylor \& Francis, London, 3-25, 2005.

Frigerio, S. and van Westen, C. J.: RiskCity and WebRiskCity: Data Collection, Display, and Dissemination in a Multi-Risk

Training Package, Cartography and Geographic Information Science, 37 (2), 119-135, 2010.

20 Giardini, D., Grünthal, G., Shedlock, K. M., and Zhang, P.: The GSHAP Global Seismic Hazard Map, in: International Handbook of Earthquake \& Engineering Seismology, edited by Lee, W., Kanamori, H., Jennings, P., and Kisslinger, C., International Geophysics Series 81 B, Academic Press, Amsterdam, 1233-1239, 2003.

Gutierrez, M., Coulter, B., and Goodwin, D. R.: Natural disasters workshop integrating hands-on activities, internet-based data, and GIS, Journal of Geoscience Education, 50(4), 437-448, 2002.

25 Haberle, J.: The case study Brienz 2005, "Living with Geological Risks" of the EuroGeoSurvey Workshop, Bern, Switzerland, 22 October 2014.

Hitz, O. and Hahlen, N.: Field Trip Brienz, The Flood Event of 2005 at Glyssibach in Brienz, "Living with Geological Risks" of the EuroGeoSurvey Workshop, Bern, Switzerland, 22 October 2014.

Holub, M. and Hubl, J.: Local protection against mountain hazards - state of the art and future needs, Nat Hazards Earth Syst

30 Sci., 8, 81-99, 2008.

Joost, S., Ingensand, J., Kalbermatten, M., Tanner, R.P., and Luyet, V.: Hydroweb: an Open Source educational WebGIS platform for the understanding of spatio-temporal variations of meteorological parameters at the watershed scale, in: OGRS Symposium Proceedings, Yverdon-les-Bains, Switzerland, 24-26 October 2012. 
Nat. Hazards Earth Syst. Sci. Discuss., doi:10.5194/nhess-2017-85, 2017

Manuscript under review for journal Nat. Hazards Earth Syst. Sci.

Discussion started: 1 March 2017

(C) Author(s) 2017. CC-BY 3.0 License.
Natural Hazards

and Earth System

Sciences

Discussions

(c) $\underset{\mathrm{Br}}{\mathrm{B}}$

Kiker, G. A., Bridges, T. S., Varghese, A., Seager, T. P., and Linkovjj, I.: Application of multicriteria decision analysis in environmental decision making, Integrated Environmental Assessment and Management, 1, 105-108, 2005.

Kolb, D. A.: Experiential learning: Experience as the source of learning and development, Prentice-Hall, New Jersey, 1984.

Kos, A.: Developing capacity for natural hazard management using an active learning approach and web-based geographical information, Nat. Hazards Earth Syst. Sci., 9, 85-95, doi:10.5194/nhess-9-85-2009, 2009.

Manfré, L. A., Hirata, E., Silva, J. B., Shinohara, E. J., Giannotti, M. A., Larocca, A. P. C., and Quintanilha, J. A.: An Analysis of Geospatial Technologies for Risk and Natural Disaster Management, ISPRS Int. J. Geo-Inf., 1, 166-185, 2012.

Mansourian, A., Rajabifard, A., Zoej, M. V., and Williamson, I.: Using SDI and web-based system to facilitate disaster management, Computers \& Geosciences., 32 (3), 303-315, 2006.

10 Mitchell, J. T., Borden, K. A., and Schmidtlein, M. C.: Teaching hazards geography and geographic information systems: A middle school level experience, International research in geographical and environmental education, 17(2), 170-188, 2008.

Munda, G.: Social multi-criteria evaluation (SMCE): methodological foundations and operational consequences, European Journal of Operational Research, 158, 662 - 677, 2004.

Müller, M., Vorogushyn, S., Maier, P., Thieken, A. H., Petrow, T., Kron, A., Büchele, B., and Wächter, J.: CEDIM Risk

15 Explorer - a map server solution in the project "Risk Map Germany", Nat. Hazards Earth Syst. Sci., 6, 711-720, doi:10.5194/nhess-6-711-2006, 2006.

Nelson News: Two Nelson photographers survive Nepal earthquake, available at: http://www.nelsonstar.com/news/301344701.html (last access: 3 February 2017), 2015.

OFEV: EconoMe, Office fédéral de l'environnement, available at: http://www.econome.admin.ch/index.php, last access: 31

20 March 2016.

Olyazadeh, R., Aye, Z.C., Jaboyedoff, M., and Derron, M.-H.: An open-source webGIS platform for rapid disaster impact assessment, Journal of Spatial Information Research, 24 (3), 203-210, doi: 10.1007/s41324-016-0017-y, 2016.

Painho, M., Peixoto, M., Cabral, P., and Sena, R.: WebGIS as a teaching tool, in: Proceedings of the ESRI UC, San Diego, CA, USA, 9-13 July 2001.

25 Pechanec, V. and Vávra, A.: Education portal on climate change with web GIS client, Journal of Cases on Information Technology (JCIT), 15(1), 51-68, 2013.

PLANAT: Debris flows Brienz (2005), available at: www.planat.ch/en/images-details/datum/2011/06/22/murgaenge-brienz2005/, last access: 21 March 2016.

RoadRisk: RoadRisk, Bundesamt für Strassen ASTRA, available at: http://www.roadrisk.admin.ch/, last access: 31 January 2017.

Rojahn, C. and Sharpe, R. L.: Earthquake Damage Evaluation Data for California, Applied Technology Council, FEMA, Redwood City, Calif., 1985.

Simonovic, S. P: Systems Approach to Management of Disasters: Methods and Applications, Wiley \& Sons Inc., New York, USA, 2010. 
Nat. Hazards Earth Syst. Sci. Discuss., doi:10.5194/nhess-2017-85, 2017

Manuscript under review for journal Nat. Hazards Earth Syst. Sci.

Discussion started: 1 March 2017

(C) Author(s) 2017. CC-BY 3.0 License.
Natural Hazards

and Earth System

Sciences

Discussions

(c) $($ P)

SMH: Nepal earthquake: Yarra Valley woman Taisha Reed talks of her narrow escape, available at:

http://www.smh.com.au/world/nepal-earthquake-yarra-valley-woman-taisha-reed-talks-of-her-narrow-escape-20150430-

1mws2y.html (last access: 3 February 2017), 2015.

Sugumaran, R., Davis, C., Meyer, J., Prato, T., and Fulcher, C.: Web-Based Decision Support Tool for Floodplain

5 Management using High Resolution DEM, Journal of Photogrammetric Engineering and Remote Sensing, 66 (10), 1261 $1265,2000$.

Sutanta, H., Rajabifard, A., and Bishop, I. D.: An Integrated Approach for Disaster Risk Reduction Using Spatial Planning and SDI Platform, in: Proceedings of the Surveying and Spatial Sciences Institute Biennial International Conference, edited by Ostendorf B., Baldock, P., Bruce, D., Burdett, M., and Corcoran, P., Surveying \& Spatial Sciences Institute, Adelaide,

10 Australia, 341-351, 2009.

Tectonics: Environmental Literacy and Inquiry Working Group, Lehigh University, available at:

http://gisweb.cc.lehigh.edu/tectonics/, last access: 16 March 2015.

Tobita, J., Fukuwa, N., and Mori, M.: Integrated disaster simulator using WebGIS and its application to community disaster mitigation activities, Journal of Natural Disaster Science, 30(2), 71-82, 2008.

15 UNISDR: Terminology - United Nations International Strategy for Disaster Reduction, available at: www.unisdr.org/we/inform/terminology (last access: 14 January 2016), 2009.

van Westen, C. J.: Remote sensing and GIS for natural hazards assessment and disaster risk management, in: Treatise on Geomorphology, edited by: Shroder, J. and Bishop, M. P., Academic Press, San Diego, CA, 3, $259-298,2013$.

Valdorisk: Manuel, Calculateur de risque pour les dangers naturels basé sur EconoMe, Version 1.4, September 2015.

20 Wang, J., Ni, H., Rui, Y., Cui, C., and Cheng L.: A WebGIS-based teaching assistant system for geography field practice (TASGFP), British Journal of Educational Technology, 47: 279-293, doi: 10.1111/bjet.12231, 2016.

Wiggins, G. and McTighe, I.: Understanding by Design, Merrill Education/ASCD, College Textbook Series, ASCD, Alexandria, Virginia, USA, 1998.

Zeleny, M.: Compromise programming, in: Multiple Criteria Decision Making, edited by: Cochrane, J. L. and Zeleny, M.,

25 University of South Carolina Press, Columbia, South Carolina, 1973.

ZHA: Zurich Hazard Analysis - Methodology, available at:

http://serverone.ch/dokumente/IT_Risikomanagement/Zurich\%20Hazard\%20Analysis.pdf, last access: 31 January 2017. 